\title{
Interactive Effects of Nitrogen and Water Addition on Soil Microbial Metabolic Limitation in Temperate Desert Shrublands
}

\section{Jiwei Li}

Institute of Soil and Water Conservation

Jiangbo Xie

State Key Lab of Desert and Oasis Ecology

\section{Yu Zhang}

Institute of Soil and Water Conservation

Dong Lingbo

Institute of Soil and Water Conservation

\section{Zhouping Shangguan}

Institute of Soil and Water Conservation

\section{Lei Deng ( $\square$ leideng@ms.iswc.ac.cn )}

Institute of Soil and Water Conservation Chinese Academy of Sciences and Ministry of Water Resources https://orcid.org/0000-0002-5898-5100

\section{Research Article}

Keywords: Desert ecosystems, Extracellular enzyme activity, Nitrogen addition, Increased precipitation, Microbial nutrient limitation

Posted Date: March 11th, 2021

DOI: https://doi.org/10.21203/rs.3.rs-269469/v1

License: (c) (1) This work is licensed under a Creative Commons Attribution 4.0 International License. Read Full License 
1 Interactive effects of nitrogen and water addition on soil microbial metabolic limitation in

\section{temperate desert shrublands}

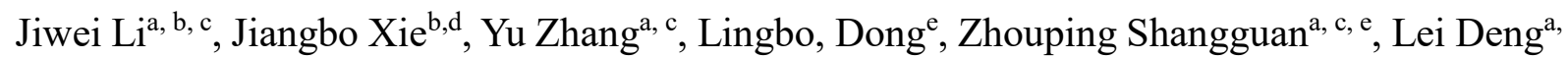
$\mathrm{c}, \mathrm{e}, \mathrm{f}^{*}$

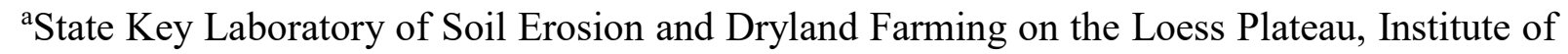
Soil and Water Conservation, Chinese Academy of Sciences and Ministry of Water Resources, Yangling, Shaanxi 712100, China

bState Key Lab of Desert and Oasis Ecology, Xinjiang Institute of Ecology and Geography, Chinese Academy of Sciences, South Beijing Road, Urumqi, Xinjiang 830011, China cUniversity of Chinese Academy of Sciences, Beijing 100049, China

${ }^{\mathrm{d}}$ State Key Laboratory of Subtropical Silviculture, Zhejiang A\&F University, Lin'an, 311300 , China

'Institute of Soil and Water Conservation, Northwest A\&F University, Yangling, Shaanxi 712100, China

${ }^{f}$ Key Laboratory of State Forestry and Grass Bureau of Loess Plateau of Shaanxi Forestry Academy of Sciences, Xi'an, Shaanxi 710021, China

\section{*Corresponding author:}

Prof. Lei Deng

Address: No. 26 Xinong Road, Yangling, Shaanxi 712100, China

Phone: 086-29-87012884, Fax: 086-29-87012210

Email: leideng@ms.iswc.ac.cn 


\section{Abstract}

Aims Soil microbes play critical roles in regulating the turnover of soil organic carbon (SOC) and nutrients, and microbial metabolic limitation should draw more attention in desert ecosystems. However, soil extracellular enzymes activity (EEA) response and microbial metabolic limitation to atmospheric $\mathrm{N}$ deposition and increased precipitation in desertshrubland are still poorly understood.

Methods The study examined the effects of long-term ( 9 year) $\mathrm{N}$ and water additions (i.e., $5 \mathrm{~g}$ $\mathrm{N} \mathrm{m}^{-2} \mathrm{yr}^{-1}, 30 \%$ ambient precipitation increase and their combination) on EEAs and soil microbial resource limitation, as well as explored their controlling factors in the Gurbantunggut Desert in northwestern China.

Results The results showed that $\mathrm{N}$ and water additions significantly enhanced soil EEAs and considerably aggravated microbial phosphorous (P) limitation. Water addition and the N-water combination addition alleviated carbon (C) limitation, but $\mathrm{N}$ addition alone strengthened microbial $\mathrm{C}$ limitation. The interaction of $\mathrm{N}$ and water additions relieved the negative impact of $\mathrm{N}$ addition on soil microbial $\mathrm{C}$ limitation, and positively aggravated microbial $\mathrm{P}$ limitation. Soil microbial $\mathrm{C}$ limitation was primarily driven by soil moisture and organic $\mathrm{C}$ concentration, while the soil microbial N/P limitation was chiefly controlled by soil water and available $\mathrm{P}$ contents.

Conclusions The influences of either $\mathrm{N}$ - or water addition alone on desert ecosystem biogeochemical processes may be altered by their concurrent occurrence. Overall, these findings highlight water availability is more effective at modifying microbial metabolisms than $\mathrm{N}$ accumulation in desert ecosystems. Altogether, this may help to predict how terrestrial $\mathrm{C}$ and nutrient flow could be induced by global change factors..

Key words: Desert ecosystems; Extracellular enzyme activity; Nitrogen addition; Increased precipitation; Microbial nutrient limitation 


\section{Introduction}

Drylands occupy nearly one-third of global land (Austin et al., 2004; She et al., 2018), and they are increasingly threatened by desertification under global climate change (Dillon et al., 2010; Huang et al., 2015a). Deserts belong to arid ecosystems, and are typically characterized by the stressful conditions of low water and nutrient availability for microbial metabolic activity (Belnap, 2011; Tapia-Torres et al., 2015). Microbes can secrete extracellular enzyme activity (EEA) in response to the availability of soil resource to meet their growth needs (Li et al., 2019; Sinsabaugh et al., 2009; Deng et al., 2019, 2021). Such changes reflect the biogeochemical equilibrium between the nutrient requirements of microbial communities and soil resource availability (Fanin et al., 2016; Hill et al., 2014; Moorhead et al., 2013). Deserts are expected to be substantially more sensitive to global changes (She et al., 2018; Tapia-Torres et al., 2015), such as changes in nitrogen $(\mathrm{N})$ deposition and variable precipitation (Bobbink et al., 2010; Huang et al., 2015b; She et al., 2018). Moreover, precipitation and nitrogen (N) deposition rates have been predicted to increase in the future (IPCC, 2013; Ma et al., 2020). Therefore, understanding metabolic limitations in soil microorganisms with EEAs in response to $\mathrm{N}$ and precipitation changes is critical for predicting global carbon (C) and $\mathrm{N}$ cycles for desert ecosystems.

Soil EEA stoichiometry method combines ecological stoichiometry theory (EST) and metabolic theory of ecology (MTE) (Fanin et al., 2016; Zheng et al., 2020), which can be used to predict nutrient availability in the environment and microorganism metabolic activity (Deng et al., 2019; Sinsabaugh et al., 2009; Waring et al., 2014). This approach assumes that the acquisition of organic $\mathrm{C}, \mathrm{N}$, and phosphorous $(\mathrm{P})$ can be represented by $\mathrm{C}$-acquisition enzymes (e.g., $\beta$-D-cellobiosidase, $\mathrm{CBH} ; \beta$-1,4-glucosidase, $\mathrm{BG}$ ), $\mathrm{N}$-acquisition enzymes (e.g., leucine aminopeptidase, LAP; $\beta$-1,4-N-acetylglucosaminidase, NAG), and P-acquiring enzyme (alkaline phosphatase, AP) (Deng et al., 2019; Marklein and Houlton, 2012; Waring et al., 2014). 
Soil extracellular enzyme stoichiometry (EES), as the ratio of soil EEA can reveal microbial nutrient-acquiring limitations and soil resource attainability (Jian et al., 2016; Tapia-Torres et al., 2015; Yang et al., 2020). Thus, the soil EEA stoichiometry method has received considerable attentions in tropical forests (Waring et al. 2014), temperate grasslands (Peng and Wang, 2016), peatlands (Hill et al. 2014), degraded karst regions (Chen et al., 2019), and arid and oligotrophic ecosystems (Tapia-Torres et al. 2015). Currently, a distinctive method using vector analysis has expanded the application of EST (Fanin et al., 2016; Moorhead et al., 2016), which illustrated that the microbial matabolic limitations calculated the length and angle of the vector to quantify the relative $\mathrm{C}$ versus nutrient limitation and the relative $\mathrm{P}$ versus $\mathrm{N}$ limitation. The two methods of vector analysis and enzymatic stoichiometry are effective for microbial $\mathrm{C}$ and nutrient limitations, and providing insights into the driving mechanisms of environmental variables under global change. However, to date, few studies have directly assessed how microbial nutrient limitations changes under conditions of global change in desert ecosystems.

Artificial $\mathrm{N}$ and water additions played an important role in effecting soil microbial metabolic limitations (Ma et al., 2020; Wang et al., 2015). High N inputs into the soil can alter inorganic N instability (Chen et al., 2018a; Deng et al., 2020; Marklein and Houlton, 2012; Tecon and Or, 2017), and affect the respiratory substrates for soil microbial communities and delivering of soil extracellular enzymes (Chen et al., 2018b; Luo et al., 2017; Fujita et al., 2019). Previous studies have reported that the effects of $\mathrm{N}$ addition on soil microbial $\mathrm{C}$ limitation related to $\mathrm{N}$ addition level (Fujita et al., 2019), soil physicochemical properties (Jing et al., 2020), climate conditions (Chen et al. 2018), ecosystem types (Fujita et al. 2019; Yang et al., 2020), etc. One meta-analysis studies have also demonstrated that N enrichment increased Cacquisition enzyme activities and soil microbial $\mathrm{C}$ limitation but exhibited no impact on $\mathrm{P}$ limitation in the global ecosystems (Chen et al. 2018). Additionally, increasing precipitation may directly alters the soil water availability and indirectly affects soil physicochemical 
properties such as oxygen status and $\mathrm{pH}$ (Nielsen and Ball, 2015; Tian et al., 2017), which may stimulate microbial growth and physiological activities, and affect the responses of microbial C utilization (Henry et al., 2005; Zhang et al., 2014), further affecting soil EEAs. Previous studies have reported that increased precipitation could improve BG, LAP, and AP activities in semi-arid grassland ecosystems (Ma et al., 2020) or reduce the activities of C-and P-acquisition enzymes in mixed grass prairie ecosystems (Hewins et al., 2016). However, the mechanisms of microbial resource limitation in desert shrubland remain inadequately understood. Therefore, it is needed to do more further study in varied ecosystem types due to the responses of EEAs and microbial metabolic limitations to global change depend on complex environmental factors.

The interactions of $\mathrm{N}$ and water additions have differed effect on soil microbial activities compared to their simple additive effects. Previous studies have found increased precipitation could mitigate the negative effects of $\mathrm{N}$ addition on soil bacterial diversity, but not for fungi (Ma et al., 2016, 2020). Fungi are usually more nutrient-sensitive and drought-tolerant (Manzoni et al., 2012; She et al., 2018), and show a high C use efficiency (CUE) than bacteria in barren quality substrates (Deng et al., 2019; McGuire et al., 2010). She et al. (2018) found that $\mathrm{N}$ and water addition could affect microbial community composition through altering soil resource availability in a desert shrubland. Nevertheless, the impacts of concurrent $\mathrm{N}$ and precipitation changes on soil microbial metabolic limitations have rarely been compared for arid ecosystems. It should be noted that some studies have reported that $\mathrm{N}$ addition clearly strengthens microbial $\mathrm{C}$ limitation while water addition reduces $\mathrm{C}$ limitation (Chen et al., 2018; Yuan et al., 2019). Therefore, more data is required to enhance our understanding of the response of soil microbial metabolic limitations to $\mathrm{N}$ and precipitation additions.

The mean annual precipitation and $\mathrm{N}$ deposition level in Northern China is predicted to be continuously increase in future global change (Huang et al., 2015a, 2015b; Liu et al., 2010, 2013). Conducted manipulative experiments with $\mathrm{N}$ and water additions are necessary to 
explore how ecosystem changes in northern China. Additionally, previous studies have reported that changes in edaphic factors such as soil nutrients and soil moisture, and microbial CUE can influence enzymatic stoichiometry (Deng et al., 2019; Jing et al., 2020), and thus control microbial metabolic limitation (Feng et al., 2019; Sinsabaugh et al., 2013, 2016). Therefore, the objectives of the study were to explore how $\mathrm{N}$ and water additions affected the responses of soil microbial enzyme activity and stoichiometry, and estimate how edaphic and microbial factors may contribute to the formation of microbial metabolic limitations.

\section{Materials and Methods}

Study area and experimental design

The study was performed in the Gurbantunggut Desert in northwestern China ( $44^{\circ} 17^{\prime} \mathrm{N}$, $87^{\circ} 56^{\prime} \mathrm{E}, 475 \mathrm{~m}$ a.s.1.), and the sampling area was located in the vicinity of the southeastern fringe of the desert. The study region features a mean annual precipitation of $160 \mathrm{~mm}$ and a mean annual temperature of $6.6^{\circ} \mathrm{C}$ (Huang et al., 2015b), of which $70-80 \%$ occurs from April to September. The soil was identified as desert solonetz at $0-100 \mathrm{~cm}$, with eolian sandy soil on top, and the landscape was dominated by Haloxylon ammodendron, Tamarix ramosissima, and Haloxylon persicum with a coverage of approximately 30\% (Huang et al., 2015b).

The manipulative experiment began in September 2010, featuring a completely randomized block design with four treatment factors, including: the control (CK), N fertilization $(\mathrm{N})$ and water addition $(\mathrm{W})$ individually or in combination $(\mathrm{NW})$. Each treatment in the field survey had six replicates with six blocks, and each block had four plots (corresponding to the four treatments), resulting in a total of 24 plots. Each plot was $10 \times 10 \mathrm{~m}$ in size, and the distance of the buffer area between each plot was $10 \mathrm{~m}$ in each block. For the precipitation addition (W and NW treatments), multiple tilted galvanized iron sheets known as "precipitation collection pans" were placed above the soil surface along the border of each plot. 
Each pan was erected and constructed at a slight angle with an area of $1.9 \mathrm{~m} \times 1 \mathrm{~m}$. In total, 18 precipitation pans were set up covering equally $30 \%$ of the total area of each plot. Precipitation was collected in plastic containers after each rainfall incident, and then sprinkled onto the corresponding plot by hand during the late afternoon or early morning (Huang et al., 2015b). Therefore, the $\mathrm{W}$ and NW plots received 30\% additional natural precipitation, the amount of increase that is currently predicted for northern China (Liu et al., 2010). $\mathrm{N}$ fertilizer was applied twice a year in early April and July in the liquid form of $\mathrm{NH}_{4} \mathrm{NO}_{3}$ with a total input of $5 \mathrm{~g} \mathrm{~N}$ $\mathrm{m}^{-2}$ every year, which was diluted in $15 \mathrm{~L}$ of distilled water and evenly sprayed onto the corresponding plots. Distilled water with the same amount of $\mathrm{N}$ fertilizer was also applied to the CK and W treatments. The experiment began in September 2010, while N fertilizer and the water addition treatments were applied yearly staring at the beginning of 2011 .

Soil sample collection and related soil physicochemical measurements.

After 9 years of continuous experimental treatment, 10 soil cores $(0-10 \mathrm{~cm})$ from each plot were collected and randomly mixed to form a composite sample after removing the plant debris layer using a 2-mm sieve in August 2019. The soil samples were taken into a portable cooler box and transported to the laboratory for future measurements. Then, the soil samples were divided into two parts: one subsample was air dried at room temperature for physiochemical analysis, while the other subsample was used for microbial analyses at $4{ }^{\circ} \mathrm{C}$. Furthermore, soil samples were collected from each quadrat to measure the soil bulk density and soil moisture.

About $100 \mathrm{~g}$ of fresh soil was used to determine soil moisture content (SM, \%), which was oven-drying at $105{ }^{\circ} \mathrm{C}$ for $48 \mathrm{~h}$. Soil bulk density $\left(\mathrm{BD}, \mathrm{g} \mathrm{cm}^{-3}\right)$ were determine by the ring cutting method. Soil $\mathrm{pH}$ was estimated in a 5:1 ratio of $\mathrm{CO}_{2}$-free water to soil with a $\mathrm{pH}$ meter (PHS-3C pH acidometer, China). Soil organic carbon (SOC) content were analyzed with the 
$\mathrm{H}_{2} \mathrm{SO}_{4}-\mathrm{K}_{2} \mathrm{Cr}_{2} \mathrm{O}_{7}$ by calorific boiling and combustion method (Nelson and Sommers, 1982). Soil total nitrogen (STN) content was determined by the Kjeldahl method (Bremner, 1996). Dissolved organic carbon (DOC) was measured by wet-oxidation method was extracted and measured a TOC analyzer. The contents of $\mathrm{NO}_{3}{ }^{-}-\mathrm{N}$ and $\mathrm{NH}_{4}{ }^{+}-\mathrm{N}$ (Soil available N, AN) were measured by a flow injection analyzer. Molybdenum blue method with an ultraviolet spectrophotometer (Hitachi UV2300) to determine the soil total P (TP) and available P (AP) content, which were extracted with $\mathrm{H}_{2} \mathrm{SO}_{4}-\mathrm{HClO}_{4}$ and sodium bicarbonate, respectively (Olsen and Sommers, 1982). The soil microbial biomass carbon (MBC) and nitrogen (MBN) were extracted by $100 \mathrm{~mL} 0.5 \mathrm{M} \mathrm{K}_{2} \mathrm{SO}_{4}$, and determined by the chloroform fumigation-extraction method (Vance et al., 1987). Then, the MBC and MBN were measured by a TOC analyzer (liauid TOC II, elementar, Germany), and microbial biomass phosphorus (MBP) were extracted by $0.5 \mathrm{M} \mathrm{NaHCO}_{3}$, and we assumed experimentally derived conversion efficiencies of 0.45 0.54, and 0.40 to calculate the MBC MBN, and MBP, respectively (Joergensen and Mueller, 1996).

\section{EEA assays.}

The soil potential enzyme activities including $\mathrm{C}$-acquiring $(\mathrm{BG}, \beta-1,4$-glucosidase and CBH, $\beta$-D-cellobiosidase) (Fanin et al., 2016), P-acquiring (AP) (Tapia-Torres et al., 2015; Yang et al., 2020), and N-acquiring enzymes (NAG, $\beta-1,4-\mathrm{N}$-acetylglucosaminidase and LAP, L-leucine aminopeptidase were measured (Fanin et al., 2016; Moorhead et al., 2016) using modified versions of fluorimetric methods with fluorescent substrates of 4methylumbelliferone (MUB) and 7-amino-4-methylcoumarin (AMC) for standard fluorometric techniques (Saiya-Cork et al., 2002). Soil suspensions with eight replicate wells per sample were dispensed into 96-well microplates. Fluorescence was measured with eight replicates using a microplate reader at $365-\mathrm{nm}$ excitation and a 450 -emission filter after 
incubation in the dark at $25^{\circ} \mathrm{C}$ for $4 \mathrm{~h}$ (German et al., 2011). All enzyme activities were expressed as two different units, i.e., $\mathrm{nmol} \mathrm{g}^{-1}$ soil $\mathrm{h}^{-1}$ and $\mu \mathrm{mol} \mathrm{g} \mathrm{g}^{-1} \mathrm{MBC}^{-1}$.

Enzymatic stoichiometry Calculation

$$
\text { Enzyme C:N=Ln(BG+CBH):Ln (NAG+LAP) }
$$

$$
\text { Enzyme } \mathrm{C}: \mathrm{P}=\mathrm{Ln}(\mathrm{BG}+\mathrm{CBH}): \operatorname{Ln}(\mathrm{AP})
$$

$$
\text { Enzyme N:P=Ln(NAG+LAP):Ln (AP) }
$$

\section{CUE Calculation}

CUE was calculated indirectly from the stoichiometry of SOM, microbial biomass, and enzymes using equations (1) and (2):

$$
\mathrm{CUE}_{\mathrm{C}: \mathrm{X}}=\mathrm{CUE}_{\max }\left[\mathrm{S}_{\mathrm{C}: \mathrm{X}} /\left(\mathrm{S}_{\mathrm{C}: \mathrm{X}}+\mathrm{K}_{\mathrm{X}}\right)\right]
$$

$$
\mathrm{S}_{\mathrm{C}: \mathrm{X}}=\left(1 / \mathrm{E}_{\mathrm{C}: \mathrm{X}}\right)\left(\mathrm{B}_{\mathrm{C}: \mathrm{X}} / \mathrm{L}_{\mathrm{C}: \mathrm{X}}\right)
$$

In this formulation, $\mathrm{S}_{\mathrm{C}: \mathrm{x}}$ represents the extent to which extracellular enzymatic allocations offset the differences between the elemental composition of soil resources and microbial biomass (Sinsabaugh et al., 2013; Sinsabaugh et al., 2016); $\mathrm{K}_{\mathrm{X}}$ is the half-saturation constant (0.5); $E_{C: X}$ represents the ratio of extracellular enzyme $C: N$, and $B_{C: X}$ represent the microbial biomass $\mathrm{C}: \mathrm{N}$, and $\mathrm{L}_{\mathrm{C}: \mathrm{x}}$ represent the ratio of soil organic $\mathrm{C}$ to soil total $\mathrm{N}$; $\mathrm{CUE}_{\max }$ represents the upper limit of microbial growth efficiency, and set as 0.60 according to Sinsabaugh and Shah (2016).

\section{Calculation of microbial C limitation (Vector Length) and P limitation (Vector Angle)}

Microbial metabolic limitation was measured using vector length and vector angle $\left(^{\circ}\right)$ according to the ratio of untransformed activities for all data (Chen et al., 2019). Vector lengths and angles created by the plot of proportional enzymatic $\mathrm{C}: \mathrm{N}$ versus $\mathrm{C}: \mathrm{P}$ ratios were 
calculated to illustrate the relative biological acquisition activities (Fanin et al., 2016; Feng et al., 2019). Vector length quantifies the relative $C$ versus nutrient acquisition (Feng et al., 2019), and the vector angle quantifies the relative $\mathrm{P}$ versus $\mathrm{N}$ acquisition (Feng et al., 2019; Moorhead et al., 2016).

The microbial C limitation (vector lengths).

$$
\text { Length }=\operatorname{SQRT}\left(x^{2}+y^{2}\right)
$$

The microbial N/P limitation (vector angles).

$$
\operatorname{Angle}\left({ }^{\circ}\right)=\operatorname{DEGREES}(\operatorname{ATAN2}(\mathrm{x}, \mathrm{y}))
$$

Microbial C limitation was calculated as vector length, increases with the vector length, a relatively longer vector length indicates greater C-limitation (Feng et al., 2019; Moorhead et al., 2016). Vector angle was calculated as the arctangent of the line extending from the plot origin to point $(\mathrm{x}, \mathrm{y})$, where $\mathrm{y}$ represents the relative activity of $\mathrm{C}$ - versus $\mathrm{N}$-acquiring enzymes

Calculation of $\mathrm{N}$ and water effects on micaobial metabolic limitation.

$$
[(\mathrm{NW}-\mathrm{W}) / \mathrm{W}] \times 100 \text { in the watered plot }
$$

$$
\text { Water effects: } \Delta \mathrm{C} \text { or } \Delta \mathrm{N} / \mathrm{P} \text { limitation }=[(\mathrm{N}-\mathrm{CK}) / \mathrm{CK}] \times 100 \text { in the unfertilized plots }
$$

$$
[(\mathrm{NW}-\mathrm{N}) / \mathrm{N}] \times 100 \text { in the fertilized plots }
$$

$\mathrm{CK}, \mathrm{N}, \mathrm{W}$, and NW refer to Control, $\mathrm{N}$ addition, increased precipitation, and addition of both. 
Statistical analysis

Prior to analysis, the response variables (e.g. soil nutrients and microbial properties) were first tested for a normal distribution (Shapiro-Wilk test, $P<0.05$ ) and homogeneity of variance (Levene's test). Variables were transformed by the Box-Cox method for non-normal or unequal variances. A Two-way Analysis of Variance (ANOVA) was applied to identify the impacts of

$\mathrm{N}$ and $\mathrm{W}$ additions alone or in combination on the means of soil physicochemical properties, soil enzyme activities, and microbial metabolic limitations. Mean comparisons were determined using Tukey multiple comparison post-hoc tests $(P<0.05)$. Then linear mixed effects models (LMEE) were applied to examine the main effects of $\mathrm{N}, \mathrm{W}$ and their interaction on these soil and microbial properties using the "lme" package in R software v.3.5.0. In this model, block was treated as fixed the random effect, $\mathrm{N}$ and $\mathrm{W}$ were set as fixed effects. Correlations among soil enzyme activities, microbial metabolic limitation, and environmental factors were examined using a two-tailed Pearson rank-order correlation test. Moreover, a variation partitioning analysis (VPA) was utilized to determine the influence of environmental AMOS software version 22.0.

\section{Results}

Soil enzyme activity in response to $\mathrm{N}$ and water additions

The soil enzyme activities (represented as nmol $\mathrm{g}^{-1}$ soil and $\mathrm{nmol}^{-1} \mathrm{MBC}$ ) differed 
acquiring enzyme activity $(\mathrm{BG}+\mathrm{CBH})$ by $42.5 \%, 67.6 \%$, and $69.4 \%$ (Fig. $1 \mathrm{~A})$ and the Pacquiring enzyme activity (AP) by $31.8 \%, 166.6 \%$ and $218.9 \%$ (Fig. 1C). N addition significantly decreased the activities of $\mathrm{N}$-acquiring enzymes (NAG+LAP) by 16.2\% (Fig. 1B), while $\mathrm{N}$ and NW additions significantly increased $\mathrm{N}$-acquiring enzyme activities. There had no interactive effects of $\mathrm{N}$ addition with $\mathrm{W}$ addition on the $\mathrm{C}$-acquiring enzyme activity (Fig. 1A), but the interaction effects of $\mathrm{N}$ and $\mathrm{W}$ addition on the activities of $\mathrm{C}$ - and $\mathrm{N}$-acquiring enzymes were observed (Figs. 1B and 1C).

$\mathrm{N}, \mathrm{W}$ and $\mathrm{NW}$ additions significantly increased specific activities of $\mathrm{C}$-acquiring enzymes by $31.5 \%, 29.7 \%$, and $15.9 \%$ (Fig. 1D) and specific activities of P-acquiring enzymes by $23.3 \%$, $113.1 \%$ and $121.4 \%$ (Fig. 1F), respectively. There were no significant differences in specific activities of $\mathrm{C}$-acquiring enzyme between $\mathrm{N}$ and $\mathrm{W}$ additions (Fig.1D). The specific activities of $\mathrm{N}$-acquiring enzyme were only significantly higher by $17.3 \%$ under $\mathrm{W}$ addition, and significantly lower than the ambient by $22.3 \%$ under N addition (Fig. 1E). Similar to the soil enzyme activities trends, $\mathrm{N}$ and $\mathrm{W}$ additions showed no significant interaction effects $(P>0.10)$ on specific activities of $\mathrm{C}$-acquiring enzymes, but exerted significant interactive effects on the specific activities of $\mathrm{N}$ - and $\mathrm{P}$-acquiring enzymes.

\section{Figure 1}

Relative C-, N-, and P-acquiring enzymatic ratios

$\mathrm{N}, \mathrm{W}$ and NW additions significantly increased the enzyme C:N ratio, and $\mathrm{N}$ addition had the strongest effect by $15.0 \%$ compared with the ambient $\mathrm{N}$. NW addition significantly reduced the enzyme $\mathrm{C}: \mathrm{P}$ ratio ratio compared to the $\mathrm{N}$ addition, but there were no significant differences between the W and NW additions (Fig. 2A). N addition significantly increased the enzyme C:P ratio ratio, but $\mathrm{W}$ and $\mathrm{NW}$ additions significantly decreased the enzyme C:P ratio ratio (Fig. 2B). N, W and NW additions significantly reduced the enzyme N:P ratio ratio by $10.1 \%, 13.3 \%$, 
and $18.7 \%$, respectively. $\mathrm{N}$ and $\mathrm{W}$ additions showed no significant interaction effects $(P>0.10)$ on enzyme C:N ratio, but exerted significant interactive effects on the of enzyme C:P and N:P ratios. Furthermore, there were significant relationships between the changes in the $\mathrm{C}$-acquiring enzymes and $\mathrm{N}$-acquiring enzymes $\left(\mathrm{R}^{2}=0.61, P=0.008\right.$, Fig. 2D), C-acquiring enzymes and $\mathrm{P}$ acquiring enzymes $\left(\mathrm{R}^{2}=0.76, P<0.001\right.$, Fig. $\left.2 \mathrm{E}\right)$, and ratios of $\mathrm{N}$-acquiring enzymes and $\mathrm{P}$ acquiring enzymes $\left(\mathrm{R}^{2}=0.77, P<0.001\right.$, Fig. $\left.2 \mathrm{~F}\right)$.

Figure 2

Vector analysis characteristics of extracellular enzyme stoichiometry for microbial metabolic limitations

The vector characteristics of enzymatic stoichiometry differed between the N, W and NW additions. $\mathrm{N}$ and water additions had led to microbial $\mathrm{P}$ limitation in the temperate desert (Fig. 3A). $\mathrm{N}$ addition increased the microbial $\mathrm{C}$ limitation (vector length) by $19 \%$, while the $\mathrm{W}$ and NW additions reduced the vector length by $10.4 \%$ and $9.6 \%$, respectively. NW addition significantly decreased microbial C limitation compared to that of W addition alone, but it had exerted significant higher on microbial C limitatio compared with that of $\mathrm{W}$ addition (Fig. 2B). $\mathrm{N}$ and $\mathrm{W}$ addition significantly and interactively affected the microbial vector angles (Fig.3C). The vector angle was significantly higher under N, W and NW additions than the ambient by $18.1 \%, 26.5 \%$, and $39.7 \%$, respectively, and the vector angles were all $>45^{\circ}$, suggesting that the soil microbial metabolism was limited by soil P. NW addition demonstrated the largest microbial $\mathrm{P}$ limitation $\left(55.8 \pm 0.5^{\circ}\right)$, and significantly increased microbial $\mathrm{P}$ limitation as compared to the $\mathrm{N}$ a or $\mathrm{W}$ additions alone (Fig.3C).

Furthermore, $\mathrm{N}$-induced increases in $\mathrm{C}$ and $\mathrm{P}$ limitations were lower in the watered plots than the unwatered plots, and $\mathrm{N}$-induced increases had a little effect on the microbial $\mathrm{C}$ 
limitation in the watered plots (Fig. 4A). The water-induced declines in C limitation were greater when fertilizer was applied, and the water-induced decreases in P limitation were lower in both $\mathrm{N}$ and ambient $\mathrm{N}$ plots (Fig. 4B). These results suggest that water may alleviate the $\mathrm{C}$ induced by $\mathrm{N}$ enrichment, while $\mathrm{N}$ and water addition in combination may decrease $\mathrm{P}$ limitation than their alone. In addition, the microbial $\mathrm{C}$ limitation was negatively correlated with microbial $\mathrm{P}$ limitation in response to $\mathrm{N}$ and water additions (Fig.3D, $P<0.05$ ).

Figure 3

Figure 4

Factors related to microbial metabolic limitation under $\mathrm{N}$ and water additions

The VPA revealed that the soil nutrients (25.8\%) and physical properties $(24.7 \%)$ explained much a substantially greater portion of the variation in microbial $\mathrm{C}$ limitation than the nutrient ratios $(10.4 \%)$ or microbial properties $(6.2 \%)$ (Fig. 5A). The physical properties and soil nutrients showed strong effects on soil microbial N/P limitation (Fig. 5B). The stepwise regression models detected that $\mathrm{SM}, \mathrm{SOC}$ and N/P were the most influential factor on microbial C limitation (Table 3), and SM, SAP, AN/SAP and MBC were the most important factors affecting the soil microbial N/P limitation (Table 3).

The SEM analysis demonstrated that soil moisture and SOC directly and indirectly affected microbial $\mathrm{C}$ limitation, and N/P exhibited direct effects on microbial C limitation (Fig. 6A). SM, SAP, AN/SAP, and MBC directly and indirectly affected on microbial N/P limitation, and MBC exhibited direct effects on microbial N/P limitation (Fig. 6B). SM and SOC exerted significantly negative direct effects on microbial C limitation (Fig. 6A), while SM and SAP significantly positively, and directly affected microbial N/P limitation (Fig. 6B). SM was the common significant driver of microbial $\mathrm{C}$ and $\mathrm{N} / \mathrm{P}$ limitation. The correlation analysis also revealed that microbial C limitation were negatively correlated with SM and SOC but positively 
correlated with N/P. The microbial N/P limitation were positively correlated with $\mathrm{SM}$ and AN/SAP but negatively correlated with SAP and MBC (Fig. S1).

\section{Figure 5}

Figure 6

\section{Discussion}

$\mathrm{C}-, \mathrm{N}$ - and $\mathrm{P}$-acquiring enzymes responses to $\mathrm{N}$ and water additions

Shifts in $\mathrm{N}$ and precipitation can alter biogeochemical cycles and affect soil and microbial community functions (Bai et al., 2020; Saiya-Cork et al., 2002; Wang et al., 2015). N addition and increased precipitation enhanced $\mathrm{C}$ - and $\mathrm{P}$-acquiring enzyme activities, and similar findings for specific enzyme activities were also observed. The increase in $\mathrm{C}$ - and P-acquiring enzyme activities altered by $\mathrm{N}$ addition may have been due to the increase in soil available nutrients (eg., DOC and $\mathrm{NH}_{4}{ }^{+}, \mathrm{NO}_{3}{ }^{-}$, Table 1 and 2), which may have stimulated the synthesis and excretion of soil extracellular enzymes by microbes (Burns et al., 2013; Zhao et al., 2018). N addition had reduced $\mathrm{N}$-acquiring enzyme activities in both normal and specific form, this may have been related to soil acidification by $\mathrm{N}$-addition, while in the current study insignificant changes shown that (Table 1 and 2). Soil pH strongly affects the denaturation of enzyme active centers and enzyme folding (Ma et al., 2015; Zeglin et al., 2007). Significant negative correlations between soil $\mathrm{pH}$ and $\mathrm{N}$-acquiring enzyme activities were also recorded (Fig. S1). In contrast to $\mathrm{N}$ addition, water addition caused a decline of the soil $\mathrm{N}$-acquiring enzyme activities, which agrees with the results of Akinyemia et al. (2020). Since the desert environment was water-stressed, water addition may have alleviated the stress and aided soil nutritional compound uptake by the soil (Feng et al., 2019; Nielsen and Ball, 2015). This would revived dormant microbes and increased their activity, thus up-regulating enzymatic production (She et al., 2018; Tecon and Or, 2017; Wang et al., 2015), which is a likely mechanism to explain 
our findings.

Water addition exhibited a greater impact on inducing soil EEAs (except specific Cacquiring enzyme activities, Fig.1), due to the water-stress being more severe than the $\mathrm{N}$ limitation in the desert environment. Moreover, it was demonstrated that $\mathrm{N}$ and water additions in combination significantly improved soil EEAs as compared to $\mathrm{N}$ addition alone (Fig. 1), as the findings that the impacts of $\mathrm{N}$ on soil EEAs may be strengthened by soil water accumulation (Ma et al., 2020; Wang et al., 2015; Yang et al., 2017). However, NW addition displayed no effects on C-acquiring enzyme activities compared to that of W addition (Figs. 1A and 1C). The inconsonant changes of soil EEA types emphasize that intrinsic variations in the microbe metabolic activity should also be considered to help explain the $\mathrm{C}$ and nutrients chain cycles (Chen et al., 2018; Feng et al., 2019; Vitousek et al., 2010; Yang et al., 2020). In addition, water addition masked the positive effects by $\mathrm{N}$ deposition in $\mathrm{C}$-acquiring enzyme activities (Fig. 1A), offset the negative effects on the N-acquiring enzyme (Fig. 1B), and enhanced the positive effects on P-acquiring enzyme (Fig. 1C) by $\mathrm{N}$ deposition. These results indicate that water availability exhibited greater effects than those of soil $\mathrm{N}$ resources. The reinforcement in $\mathrm{C}$ - and P- acquiring enzyme activities under NW addition may have been due to the increased water status, and nutrients may have activated soil microbial activity for their own growth (Gutknecht et al., 2010; Li et al., 2019), resulting in a large requirement of C and $\mathrm{P}$ to synthetize ribosomal RNA (Deng et al., 2019; Henry et al., 2005). However, the negative effect of $\mathrm{N}$ deposition was offset by improved soil water, which is in line with the results of previous studies (Ma et al., 2020; Yang et al., 2017; Zhu et al., 2020). One potential mechanism for this may be that increased water availability accelerated the soil $\mathrm{N}$ leaching (Tian et al., 2017), thereby enhancing the nutrient demand of microbes (Henry et al., 2005; Wang et al., 2016; Zeglin et al., 2007), consequently weakening the accumulation of $\mathrm{N}$ in the soil, and shifting the production of N-acquiring enzyme activities (Harpole et al., 2007; Nielsen and Ball, 2015; Tian et al., 2017). 
Microbial metabolic limitation responses to $\mathrm{N}$ and water additions

The ratios of enzymatic C:N and C:P (Figs. 2A and 2B) and vector length (Fig. 3B) were enhanced under improved $\mathrm{N}$ availability, whereas enzymatic N:P decreased (Fig. 2C). These results indicate that $\mathrm{N}$ addition elevated the $\mathrm{C}$ limitation and alleviated the microbial demand for N (Chen et al., 2018b; Yuan et al., 2019; Zhu et al., 2020). N addition provided sufficient available $\mathrm{N}$ for microorganism growth (Deng et al., 2020), and mitigated the N-limitation (Jian et al., 2016; Wang et al., 2015). However, $\mathrm{N}$ addition may have also enhance the $\mathrm{N}$ and $\mathrm{P}$ contents in plant litter and retarded the mineralization of old SOM (Chen et al., 2019), hence reducing the ratios of soil $\mathrm{C}: \mathrm{N}$ and $\mathrm{C}: \mathrm{P}$ (Table 1 and 2), which would further increase the soil available C content (Yuan et al., 2019; Zechmeister-Boltenstern et al., 2015). Also, N addition aggravated $\mathrm{P}$ limitation, corresponding elevated ratios of enzyme $\mathrm{C}: \mathrm{P}$ and N:P (Figs. $2 \mathrm{~B}$ and 2C) and vector angles (Fig. 3C). This could have been related to the fresh $\mathrm{P}$ being derived chiefly from rock weathering (Tapia-Torres et al., 2015; Wang et al., 2015), and therefore, not having been able to reach the $\mathrm{C}$ and $\mathrm{N}$ levels (Vitousek et al., 2010). In addition, $\mathrm{N}$ addition could have decreased the relative abundance of arbuscular mycorrhizal fungi (AMF), causing a lower fungi:bacteria ratio (Ren et al., 2017; Waldrop et al., 2004; Zeglin et al., 2007). AMF also likely played a substantial role in mineral nutrition absorption (particularly P) and could have promoted the growth of P-solubilizing bacteria (Li et al., 2020; McGuire et al., 2010; Wang, 2017), thus, reducing the allocation of $\mathrm{P}$ to microbial nutrient activity (Xu et al., 2020; Zhao et al., 2018).

Water addition decreased the soil microbial $\mathrm{C}$ limitation with significantly lower enzyme $\mathrm{C}: \mathrm{N}$ and $\mathrm{C}: \mathrm{P}$ ratios and vector length compared to non-NW additions. The potential mechanism for this may be that elevated water availability accelerated plant and root residue incorporation into SOM (Nielsen and Ball, 2015; She et al., 2018) and enhanced the soil $\mathrm{C}$ and $\mathrm{N}$ pools in the 
water-limited environment, thus alleviating the microbial C limitation (Deng et al., 2019; Tian et al., 2017). However, water addition also could aggravate $\mathrm{C}$ limitation (Akinyemi et al., 2020; Waring et al., 2014; Wang et al., 2015), because the differences in the initial soil environment, rainfall amount and intensity, and dominant community (Hewins et al., 2016; Jing et al., 2020; Nielsen and Ball, 2015). Furthermore, the study found that water addition induced microbial $\mathrm{N}$ to P limitation in desert ecosystems (Fig. 3C), because increased water availability which could have increased the net primary productivity and promoted the reabsorption of $\mathrm{P}$ by plants (Ma et al., 2020; Wang et al., 2015; Zechmeister-Boltenstern et al., 2015), and thus reducing the available $\mathrm{P}$ for microorganisms.

The study demonstrated that $\mathrm{N}$ and water additions showed significantly interactive effects on decreasing the $\mathrm{C}$ limitation (Figs. 2A, 2B, and 3B). However, the simultaneous $\mathrm{N}$ and water addition had no apparent effect on microbial $\mathrm{C}$ limitation relative to that of the $\mathrm{W}$ addition, indicated that water addition concealed the impacts of $\mathrm{N}$ deposition on the soil microbial Cacquiring capability by altering the interception and assimilation of $\mathrm{N}$ and water. Our previous studies have demonstrated that water addition can alleviate the suppressive effects of $\mathrm{N}$ deposition on soil microbial nutrient activity (Huang et al., 2015b; Luo et al., 2017) may be one reason for this phenomenon. Additionally, microorganisms are known to enhance the denitrification of $\mathrm{N}$ through extracellular enzymes (Tian et al., 2017; Zeglin et al., 2007; Zhu et al., 2020), and improve $\mathrm{C}$ utilization under humid conditions (Feng et al., 2019; Harpole et al., 2007). In the present study, water addition could alleviate the strengthening effects of $\mathrm{N}$ deposition on soil microbial C limitations (Fig. 4), because extreme precipitation may promote soil inorganic N leaching losses and decrease microbial C demand (Gutknecht et al., 2010; Huang et al., 2015a; Ma et al., 2020), which may offset the effects of $\mathrm{N}$ deposition on microbial metabolic limitation (Henry et al., 2005). 
Although $\mathrm{N}$ and water addition in combination may decrease $\mathrm{P}$ limitation than their alone

(Fig.4), the present study found that $\mathrm{N}$ and $\mathrm{W}$ additions in combination have the greatest and interactive effects on microbial P limitation (Fig. 3C). Several mechanisms may explain the highest $\mathrm{P}$ limitation being associated with the combination of $\mathrm{N}$ addition and increased precipitation: first, long-term $\mathrm{N}$ and water addition could have caused continuous plant litter inputs, providing a suitable habitat for microbial growth (Akinyemi et al., 2020; Tian et al., 2017; Yang et al., 2017), hence, enhancing the soil C and N pools (She et al., 2018). Further, N and water additions improved the substrate availability (AN and SAP) (Table 1 and 2), which may have led to changes in soil $\mathrm{C}$ availability, plant nutrient status, and soil microbial community structure (Feng et al., 2019; Marklein et al., 2012; Henry et al., 2005). So, water addition may have led to increased $\mathrm{C}$ and $\mathrm{N}$ contents in the soils (Glaser et al., 2010; Na et al., 2019; Nielsen and Ball, 2015), and thus decreased microbial C- and N-limitations. In this way, soil microbes would tend to obtain more $\mathrm{P}$ to meet their growth requirements after the depletion of available P from the soil resources (Peng and Wang, 2016; Tapia-Torres et al., 2015), and fresh P would be chiefly derived from rock weathering (Hewins et al., 2016; Ma et al., 2020). Water addition would also activate both microbes and plants (Akinyemi et al., 2020; Hewins et al., 2016), leading to competition in P uptake between microbes and plants (Wang et al., 2014; Wang et al., 2015; Wang et al., 2020b). Consequently, $\mathrm{N}$ and water additions in combination significantly aggregated microbial P limitation in the soils.

Major factors affecting soil microbial metabolic limitation

Water and $\mathrm{N}$ availability were important factors affecting ecosystem nutrient cycling in the desert ecosystem (Austin et al., 2004; Bai et al., 2020; Bobbink et al., 2010; She et al., 2018). Soil microbial metabolic limitation not only depended on $\mathrm{N}$ and water additions, but also on the soil biotic and abiotic factors. Previous studies have reported that soil EEAs are primarily 
driven by soil matrix, nutritional status, etc. (Jing et al., 2020; Kivlin and Treseder, 2014), instead of soil microorganisms and plants (Pan et al., 2013). In the present study, soil nutrients had the predominant effects on soil C and N/P limitations. Similarly, Kivlin and Treseder (2014) demonstrated that soil $\mathrm{C}$ and $\mathrm{N}$ contents has the greatest effects on soil EEAs in grasslands of southern California, USA. Ma et al. (2020) indicated that soil EEAs were chiefly driven by the $\mathrm{N}$ and $\mathrm{P}$ contents related to global change. These results indicated that the soil nutrient element concentrations are key factors affecting soil microbial nutrient (Jing et al., 2020; Ma et al., 2020; Sinsabaugh et al., 2009). This may be partly explained by the fact that soil nutrient contents can alter soil EEAs and enzymatic stoichiometry by affecting soil stoichiometry and soil substrate availability (Ma et al., 2020; Yang et al., 2020). Moreover, soil physical properties exhibited a strong role in microbial $\mathrm{C}$ and N/P limitations, which is most likely due to the effects of soil water availability (Table 3), further confirming their key role in controlling plant and microbial growth by the soil water availability in arid ecosystems (Deng et al., 2019; Feng et al., 2019).

Previous studies have indicated that soil water availability plays a key role in nutrient diffusion and stock in the soil (Chapman et al. 2012; Wang et al., 2020b; Zhang et al. 2014). Soil water availability is vital for both microbial activities and plant growth (Deng et al., 2019; Ma et al., 2020), thereby affecting litter decomposition, particularly in dry ecosystems (Bell et al., 2008; Chapman et al., 2012; Su et al., 2020). Higher plant litter input may provide sufficient C sources for SOM decomposition (Deng et al., 2019), leading to a higher SOC content (Nielsen and Ball, 2015; Peng and Wang, 2016). Soil microbes produce extracellular enzymes that catalyze the SOC mineralization and convert nutrients from organic into inorganic forms (Fanin et al., 2016; Ma etal., 2020; Na et al., 2019; Zechmeister-Boltenstern et al., 2015), thus providing sufficient $\mathrm{C}$ sources to feed microbial growth and reproduction (Li et al., 2019), and less restricted by $\mathrm{C}$ in the long term for microbial communities (Ma et al., 2020; Tapia-Torres 
Soil moisture and SAP were strong controlling factors influencing microbial metabolic limitation in the desert shrublands (Table 3). Drought is beneficial to the release of soil P via geochemical weathering (Feng et al., 2019; Wang et al., 2020b; Tapia-Torres et al., 2015; Wang et al., 2015), however, increased water availability promotes the loss of soil $\mathrm{P}$ through leaching (Akinyemi et al., 2020), thereby decreasing the soil $\mathrm{P}$ availability and thus leading to $\mathrm{P}$ limitation. In addition, water may supply more nutrients and stimulate the growth of vegetation and microbial communities, which can aggravate the competition between plants and microbes for soil available P (Ma et al., 2020; Wang et al., 2014). Xu et al., (2020) reported that soil water and available $\mathrm{P}$ were the major factors affecting nutrient resorption strategies. A close competition between plants and microbes may occur after $\mathrm{N}$ and water addition (Nielsen and Ball, 2015; Wang et al., 2020b; Zechmeister-Boltenstern et al., 2015). Furthermore, soil water and available P may alter the abundance of AMF (Huang et al., 2015a; Kivlin and Treseder, 2014; Ma et al., 2020). A recent study found that global change and AMF had interactive effects on soil available P (Mei et al., 2019), which determined microbial nutrient absorption (Bünemann et al., 2004; Ma et al., 2020). In general, the study found that soil moisture was the most common driver of microbial $\mathrm{C}$ and $\mathrm{P}$ limitations, because water availability is the primary limiting factor on microbial metabolic activity in desert ecosystems.

\section{Conclusions}

This study revealed that $\mathrm{N}$ and water additions significantly enhanced EEAs. $\mathrm{N}$ addition aggravated microbial $\mathrm{C}$ and $\mathrm{P}$ limitations, whereas water addition was found to intensify microbial $\mathrm{P}$ limitations. $\mathrm{N}$ and water additions showed interactive effects on microbial metabolic limitation. The interactions of $\mathrm{N}$ and $\mathrm{W}$ could offset the impacts of $\mathrm{N}$ deposition and 
was found to decrease soil microbial $\mathrm{C}$ limitation while strengthening the effects of $\mathrm{N}$ and water

addition alone, resulting in an increased $\mathrm{P}$ limitation. Moreover, soil microbial $\mathrm{C}$ limitation was

chiefly driven by soil moisture and SOC in the desert shrublands, whereas soil microbial N/P

limitation was controlled by soil moisture and SAP contents. Soil water availability in the desert ecosystems played prominent role in effecting on soil microbial metabolic limitation. Future $\mathrm{N}$ deposition and increased precipitation are likely to alleviate or aggravate microbial metabolic limitation.

\section{Acknowledgements}

This study was supported by the National Natural Science Foundation of China (41730638), the Second Tibetan Plateau Scientific Expedition and Research Program (2019QZKK0603), the Strategic Priority Research Program of the Chinese Academy of Sciences (XDA23070201, XDB40000000), and the Funding of Special Support Plan of Young Talents Project of Shaanxi Province and National Forestry and Grassland Administration in China (20201326015).

\section{Supplementary information}

Supplementary material can be found for the online version. Appendix Fig.S1.

\section{References}

Akinyemi DS, Zhu Y., Zhao M., Zhang P., Shen H, Fang J (2020) Response of soil extracellular enzyme activity to experimental precipitation in a shrub-encroached grassland in Inner Mongolia. Glob Ecol Conserv e01175.

Austin AT, Yahdjian L Stark JM, Belnap J, Porporato A, Norton U, Ravetta DA, Schaeffer SM (2004). Water pulses and biogeochemical cycles in arid and semiarid ecosystems. Oecologia 141, 221-235.

Bai TS, Wang P, Hall SJ, Wang FW, Ye CL, Li Z, Li SJ, Zhou LY, Qiu YP, Guo JX, Guo H, Wang Y, Hu S (2020) Interactive global change factors mitigate soil aggregation and carbon change in a semi arid grassland. Glob Change Biol 00, 1-13.

Belnap J (2011) Biological Phosphorus Cycling in Dryland Regions. Springer Berlin Heidelberg.

Bobbink R, Hicks K, Galloway J, Spranger T, Alkemade R, Ashmore M, Bustamante M, Cinderby S, Davidson E, Dentener F, Emmett B, Erisman JW, Fenn M, Gilliam F, Nordin A, Pardo L, De Vries W (2010) Global assessment of nitrogen deposition effects on terrestrial plant diversity: a synthesis. Ecol Appl 20, 30-59.

Bremner, J (1996) Nitrogen-total. Methods of soil analysis part 3, chemical methods (methodsofsoilan3), 1085-1121.

Bünemann EK, Bossio DA, Smithson PC, Frossard E, Oberson A ( 2004) Microbial community composition and substrate use in a highly weathered soil as affected by crop rotation and P fertilization. Soil Biol Biochem 36, 889-901.

Burns RG, DeForest JL, Marxsen J, Sinsabaugh RL, Stromberger ME, Wallenstein MD, 
Weintraub MN, Zoppini A (2013) Soil enzymes in a changing environment: current knowledge and future directions. Soil Biol Biochem 58, 216-234.

Chapman N, Miller AJ, Lindsey K, Whalley WR (2012) Roots, water, and nutrient acquisition: let's get physical. Trends Plant Sci. 17, 701-710.

Chen H, Li DJ, Zhao J, Xiao KC, Wang KL (2018a) Effects of nitrogen addition on activities of soil nitrogen acquisition enzymes: A meta-analysis. Agric Ecosyst Environ 252, $126-$ 131.

Chen H, Li DJ, Zhao J, Zhang W, Xiao KC, Wang KL (2018b) Nitrogen addition aggravates microbial carbon limitation: Evidence from ecoenzymatic stoichiometry. Geoderma 329, 61-64.

Chen H, Zheng MH. Mao QG, Xiao KC, Wang KL, Li DJ (2019) Cropland conversion changes the status of microbial resource limitation in degraded karst soil. Geoderma 352, 197-203.

Deng L, Peng CH, Huang CB, Wang KB, Liu QY, Liu YL, Hai XY, Shangguan ZP (2019) Drivers of soil microbial metabolic limitation changes along a vegetation restoration gradient on the Loess Plateau, China. Geoderma 353, 188-200.

Deng, L, Huang CB, Kim DG, Shangguan ZP, Wang KB, Song XZ, Peng CH (2020) Soil GHG fluxes are altered by $\mathrm{N}$ deposition: new data indicate lower $\mathrm{N}$ stimulation of the $\mathrm{N}_{2} \mathrm{O}$ flux and greater stimulation of the calculated C pools. Glob. Change Biol. 26, 2613-2629.

Deng L, Peng CH, Li JW, Liu YL, Hai XY, Liu QY, Huang CB, Shangguan ZP, Kuzyakov Y (2021) Effects of droughts on soil carbon and nitrogen dynamics in natural ecosystems. Earth-Science Reviews 214, 103501.

Dillon ME, Wang G, Huey RB (2010) Global metabolic impacts of recent climate warming. Nature 467, 704-706.

Dong S, Shang Z, Gao J, Boone RB (2020) Enhancing sustainability of grassland ecosystems through ecological restoration and grazing management in an era of climate change on Qinghai-Tibetan Plateau. Agric Ecosyst Environ 287, 106684.

Fanin N, Moorhead D, Bertrand I (2016) Eco-enzymatic stoichiometry and enzymatic vectors reveal differential $\mathrm{C}, \mathrm{N}, \mathrm{P}$ dynamics in decaying litter along a land-use gradient. Biogeochemistry 129, 21-36.

Feng J, Wei K, Chen Z, Lü X, Tian J, Wang C, Chen L (2019) Coupling and decoupling of soil carbon and nutrient cycles across an aridity gradient in the drylands of northern China: evidence from ecoenzymatic stoichiometry. Global Biogeochem Cycles 33, 559-569.

Fierer N, Leff JW, Adams BJ, Nielsen UN, Bates ST, Lauber CL, Owens S, Gilbert JA, Wall DH, Caporaso JG (2012) Cross-biome metagenomic analyses of soil microbial communities and their functional attributes. Proc National Acade Sci 109, 21390-21395.

Fujita K, Miyabara Y, Kunito T (2019) Microbial biomass and ecoenzymatic stoichiometries vary in response to nutrient availability in an arable soil. Eur J Soil Biol 91, 1-8.

German D P, Weintraub M N, Grandy A S, Lauber C L, Rinkes Z L, Allison SD (2011) Optimization of hydrolytic and oxidative enzyme methods for ecosystem studies. Soil Bio. Biochem 43, 1387-1397.

Glaser K, Hackl E, Inselsbacher E, Strauss J, Wanek W, Zechmeister-Boltenstern S, Sessitsch A (2010) Dynamics of ammonia-oxidizing communities in barley-planted bulk soil and rhizosphere following nitrate and ammonium fertilizer amendment. FEMS Microbiol Ecol $74,575-591$.

Grömping U (2006) Relative importance for linear regression in R: the Package relaimpo. Journal of Statistical Software 17, 1-27.

Gutknecht JLM, Henry HAL, Balser TC (2010) Inter-annual variation in soil extra-cellular enzyme activity in response to simulated global change and fire disturbance. Pedobiologia 53, 283-293. 
Han XY, Gao GY, Chang RY, Li ZS, Ma Y, Wang S, Wang C, Lü YH, Fu BJ (2018) Changes in soil organic and inorganic carbon stocks in deep profiles following cropland abandonment along a precipitation gradient across the Loess Plateau of China. Agric Ecosyst Environ 258, 1-13.

Harpole WS, Potts DL, Suding KN (2007) Ecosystem responses to water and nitrogen amendment in a California grassland. Global Change Biol 13, 2341-2348.

Henry HAL, Juarez JD, Field CB, Vitousek PM (2005) Interactive effects of elevated $\mathrm{CO}_{2}, \mathrm{~N}$ deposition and climate change on extracellular enzyme activity and soil density fractionation in a California annual grassland. Global Change Biol 142, 465-473.

Hewins DB, Broadbent T, Carlyle CN, Bork EW, 2016. Extracellular enzyme activity response to defoliation and water addition in two ecosites of the mixed grass prairie. Agric Ecosyst Environ 230, 79-86.

Hill BH, Elonen CM, Jicha TM, Kolka RK, Lehto LLP, Sebestyen SD, Seifert-Monson LR (2014) Ecoenzymatic stoichiometry and microbial processing of organic matter in northern bogs and fens reveals a common P-limitation between peatland types. Biogeochemistry 120, 203-224.

Huang G, Li Y, Su YG (2015a) Effects of increasing precipitation on soil microbial community composition and soil respiration in a temperate desert, Northwestern China. Soil Biol Biochem 83, 52-56.

Huang G, Li Y, Su YG (2015b )Divergent responses of soil microbial communities to water and nitrogen addition in a temperate desert. Geoderma 251, 55-64.

Luo Q, Gong J, Yang L, Li X, Pan Y, Liu M, Baoyin, TT (2017). Impacts of nitrogen addition on the carbon balance in a temperate semiarid grassland ecosystem. Biol Fertil Soils 53, 911-927.

Jian SY. Li JW, Chen J, Wang GS, Mayes MA, Dzantor KE, Hui DF, Luo YQ (2016) Soil extracellular enzyme activities, soil carbon and nitrogen storage under nitrogen fertilization: A meta-analysis. Soil Biol Biochem 101, 32-43.

Jing X, Chen X, Fang JY, Ji CJ, Shen HH, Zheng CY, Zhu B (2020) Soil microbial carbon and nutrient constraints are driven more by climate and soil physicochemical properties than by nutrient addition in forest ecosystems. Soil Biol Biochem 141, 107657.

Joergensen RG and Mueller T (1996) The fumigation-extraction method to estimate soil microbial biomass: calibration of the kEN value. Soil Biol Biochem 28, 33-37.

Kivlin SN, Treseder KK (2014) Soil extracellular enzyme activities correspond with abiotic factors more than fungal community composition. Biogeochemistry 117, 23-37.

Li JW, Liu YL, Hai XY, Shangguan ZP, Deng L (2019) Dynamics of soil microbial C:N:P stoichiometry and its driving mechanisms following natural vegetation restoration after farmland abandonment. Sci Total Environ 693, 133613.

Li JW, Shangguan ZP, Deng L (2020 Dynamics of soil microbial metabolic activity during grassland succession after farmland abandonment. Geoderma 363, 114167.

Liu L, Gundersen P, Zhang T, Mo JM (2012) Effects of phosphorus addition on soil microbial biomass and community composition in three forest types in tropical China. Soil Biol Biochem 44, 31-38.

Lü XT, Hu YY, Zhang HY, Wei HW, Hou SL, Yang GJ, Liu ZY, Wang XB (2018) Intraspecific variation drives community-level stoichiometric responses to nitrogen and water enrichment in a temperate steppe. Plant Soil 423, 307-315.

Liu YX, Li X, Zhang Q, Guo YF, Gao G, Wang JP (2010) Simulation of regional temperature and precipitation in the past 50 years and the next 30 years over China. Quat Int 212, 5763.

Ma HK, Bai GY, Sun Y, Kostenko O, Zhu X, Lin S, Ruan WB, Zhao NX, Bezemer TM (2016) 
Opposing effects of nitrogen and water addition on soil bacterial and fungal communities in the Inner Mongolia steppe: A field experiment. Appl Soil Ecol 108, 128-135.

Ma WJ, Li J, Gao Y, Xing F. Sun SN, Zhang T, Zhu XC, Chen C, Li Z (2020) Responses of soil extracellular enzyme activities and microbial community properties to interaction between nitrogen addition and increased precipitation in a semi-arid grassland ecosystem. Sci Total Environ 703, 134691.

Manzoni S, Schimel J P, and Porporato A (2012) Responses of soil microbial communities to water stress: results from a meta-analysis. Ecology 93, 930-938.

Marklein AR, Houlton BZ (2012) Nitrogen inputs accelerate phosphorus cycling rates across a wide variety of terrestrial ecosystems. New Phytol 193, 696-704.

McGuire KL, Bent E, Borneman J, Majumder A, Allison SD, Treseder KK (2010) Functional diversity in resource use by fungi. Ecology 91, 2324-2332.

Mei LL, Yang X, Zhang SQ, Zhang T, Guo JX (2019) Arbuscular mycorrhizal fungi alleviate phosphorus limitation by reducing plant $\mathrm{N}: \mathrm{P}$ ratios under warming and nitrogen addition in a temperate meadow ecosystem. Sci Total Environ 686, 1129-1139.

Moorhead DL, Rinkes ZL, Sinsabaugh RL, Weintraub MN (2013) Dynamic relationships between microbial biomass, respiration, inorganic nutrients and enzyme activities: informing enzyme-based decomposition models. Front Microbiol. 4, 223.

Moorhead DL, Sinsabaugh RL, Hill BH, Weintraub MN (2016) Vector analysis of ecoenzyme activities reveal constraints on coupled C, N and P dynamics. Soil Biol Biochem 93, 1-7.

Na XF, Yu HL, Wang P Zhu WW, Niu YB, Huang JY (2019) Vegetation biomass and soil moisture coregulate bacterial community succession under altered precipitation regimes in a desert steppe in northwestern China. Soil Biol Biochem 136, 107520.

Nelson DW, Sommers LE (1982) Total carbon, organic carbon and organic matter. In: Page AL, Miller RH, Keeney DR (eds) Methods of soil analysis, part 2. American Society of Agronomy, Madison, pp. 539-579.

Nielsen UN, Ball BA (2015) Impacts of altered precipitation regimes on soil communities and biogeochemistry in arid and semi-arid ecosystems. Global Change Biol 1407-1421.

Niu S, Yang H, Zhang Z, Wu M, Lu Q, Li L, Wan S (2009) Non-additive effects of water and nitrogen addition on ecosystem carbon exchange in a temperate steppe. Ecosystems, 12, 915-926.

Olsen SR and Sommers LE (1982) Phosphorus: Phosphorus soluble in sodium bicarbonate. In Methods of Soil Analysis, Part 2, Chemical and Microbiological Properties. 2nd ed. Eds A L Page, R H Miller and D R Keeney. pp. 421-422. Am Soc Agron, Madison, WI

Pan CC, Liu CA, Zhao HL, Wang Y (2013) Changes of soil physico-chemical properties and enzyme activities in relation to grassland salinization. Eur J Soil Biol 55, 13-19.

Paredes SH, Lebeis SL (2016) Giving back to the community: microbial mechanisms of plantsoil interactions. Funct Ecol 30, 1043-1052.

Peng XQ, Wang W (2016) Stoichiometry of soil extracellular enzyme activity along a climatic transect in temperate grasslands of northern China. Soil Biol Biochem 98, 74-84.

Powell JR, Rillig MC (2018) Biodiversity of arbuscular mycorrhizal fungi and ecosystem function. New Phytol 220, 1059-1075.

Ren CJ, Zhao FZ, Shi Z, Chen J, Han XH, Yang GH, Feng YZ (2017) Differential responses of soil microbial biomass and carbon-degrading enzyme activities to altered precipitation. Soil Biol Biochem 115, 1-10.

Tecon R, Or D (2017) Biophysical processes supporting the diversity of microbial life in soil. FEMS Microbiol. Rev. 41, 599-623.

Saiya-Cork KR, Sinsabaugh RL, Zak DR (2002) The effects of long term nitrogen deposition on extracellular enzyme activity in an Acer saccharum forest soil. Soil Biol Biochem 34, 
1309-1315.

Schleuss PM, Widdig M, Heintz-Buschart A, Guhr A, Martin S, Kirkman K; Spohn, M (2019) Stoichiometric controls of soil carbon and nitrogen cycling after long-term nitrogen and phosphorus addition in a mesic grassland in South Africa. Soil Biol Biochem 135, 294 303.

She WW, Bai, YX, Zhang Y.Q, Qin SG, Feng W, Sun YF, Zheng J, Wu B (2018) Resource availability drives responses of soil microbial communities to short-term precipitation and nitrogen addition in a desert shrubland. Front Microbiol 9, 186.

Sinsabaugh RL, Hill BH, Shah JJF (2009) Ecoenzymatic stoichiometry of microbial organic nutrient acquisition in soil and sediment. Nature 462, 122-122.

Sinsabaugh RL, Lauber CL, Weintraub MN, Ahmed B, Allison SD, Crenshaw C, Contosta A.R., Cusack D, Frey S, Gallo ME (2008) Stoichiometry of soil enzyme activity at global scale. Ecol. Lett. 11, 1252-1264.

Sinsabaugh RL, Manzoni S, Moorhead DL, Richter A (2013) Carbon use efficiency of microbial communities: stoichiometry, methodology and modelling. Ecol Lett 16, 930-939.

Sinsabaugh RL, Turner BL, Talbot JM, Waring BG, Powers JS, Kuske CR, Moorhead DL, Shah, JJF (2016) Stoichiometry of microbial carbon use efficiency in soils. Ecol Monogr 86, $172-189$.

Tapia-Torres Y, Elser JJ, Souza V, Garcia-Oliva F (2015) Ecoenzymatic stoichiometry at the extremes: How microbes cope in an ultra-oligotrophic desert soil. Soil Biol Biochem 3442.

Tian JH, Wei K, Condron LM, Chen ZH, Xu ZW, Feng J, Chen LJ (2017) Effects of elevated nitrogen and precipitation on soil organic nitrogen fractions and nitrogen-mineralizing enzymes in semi-arid steppe and abandoned cropland. Plant Soil 417, 217-229.

Vance ED, Brookes PC, Jenkinson DS (1987) An extraction method for measuring soil microbial biomass C. Soil Biol Biochem 19 703-707.

Vitousek P M, Porder S, Houlton BZ, Chadwick O A (2010) Terrestrial phosphorus limitation: mechanisms, implications, and nitrogen-phosphorus interactions. Ecological applications, 20, 5-15.

Waldrop MP, Zak DR, Sinsabaugh RL, Gallo M, Lauber C (2004) Nitrogen deposition modifies soil carbon storage through changes in microbial enzymatic activity. Ecol Appl 14, 11721177.

Wang F (2017) Occurrence of arbuscular mycorrhizal fungi in mining-impacted sites and their contribution to ecological restoration: Mechanisms and applications. Crit. Rev. Environ Sci Technol 1901-1957.

Wang JY, Ren CJ, Feng XX, Zhang L, Doughty R, Zhao FZ (2020) Temperature sensitivity of soil carbon decomposition due to shifts in soil extracellular enzymes after afforestation. Geoderma 374, 114426.

Wang RZ, Dorodnikov M, Yang S, Zhang YY, Filley TR, Turco RF, Zhang YG, Xu ZW, Li H, Jiang Y (2015) Responses of enzymatic activities within soil aggregates to 9-year nitrogen and water addition in a semi-arid grassland. Soil Biol Biochem 81, 159-167.

Wang RZ, Dungait JAJ, Buss HL, Yang S, Zhang YG, Xu ZW, Jiang Y (2016) Base cations and micronutrients in soil aggregates as affected by enhanced nitrogen and water inputs in a semi-arid steppe grassland. Sci Total Enviro. 575, 564-572.

Wang RZ, Filley TR, Xu ZW, Wang X, Li MH, Zhang YG, Luo WT, Jiang Y (2014) Coupled response of soil carbon and nitrogen pools and enzyme activities to nitrogen and water addition in a semi-arid grassland of Inner Mongolia. Plant Soil 381, 323-336.

Wang Z, Mckenna TP, Schellenberg M., Tang SM, Zhang YJ, Ta N, Na RS, Wang H (2019) Soil respiration response to alterations in precipitation and nitrogen addition in a desert steppe 
in northern China. Sci Total Environ 688, 231-242.

Wang Z, Na R, Koziol L, Schellenberg MP, Li XL, Ta N, Jin K, Wang H (2020b) Response of bacterial communities and plant-mediated soil processes to nitrogen deposition and precipitation in a desert steppe. Plant Soil 448, 277-297.

Waring BG, Weintraub SR, Sinsabaugh RL (2014) Ecoenzymatic stoichiometry of microbial nutrient acquisition in tropical soils. Biogeochemistry 117, 101-113.

Xiao L, Liu G, Li P, Li Q, Xue S (2020) Ecoenzymatic stoichiometry and microbial nutrient limitation during secondary succession of natural grassland on the loess plateau, China. Soil Till Res 200, 104605.

Xu MP, Zhong ZK, Sun ZY, Han XH, Ren CJ, Yang GH (2020) Soil available phosphorus and moisture drive nutrient resorption patterns in plantations on the Loess Plateau. For Ecol Manage 461, 117910.

Yang S, Xu ZW, Wang RZ, Zhang YY, Yao F, Zhang YG, Turco RF, Jiang Y, Zou HT, Li H (2017) Variations in soil microbial community composition and enzymatic activities in response to increased $\mathrm{N}$ deposition and precipitation in Inner Mongolian grassland. Appl Soil Ecol 119, 275-285.

Yang Y, Liang C, Li T, Cheng H, An S (2020) Soil extracellular enzyme stoichiometry reflects the shift from P-to N-limitation of microorganisms with grassland restoration. Soil Biol Biochem 107928.

Yuan XB, Niu DC, Gherardi LA, Liu YB, Wang Y, Elser JJ, Fu H (2019) Linkages of stoichiometric imbalances to soil microbial respiration with increasing nitrogen addition: Evidence from a long-term grassland experiment. Soil Biol Biochem 138, 107580.

Zechmeister-Boltenstern S, Keiblinger KM, Mooshammer M, Peñuelas J, Richter A, Sardans J, Wanek W (2015) The application of ecological stoichiometry to plant-microbial-soil organic matter transformations. Ecol Monogr 85, 133-155.

Zeglin LH, Stursova M, Sinsabaugh RL, Collins SL (2007) Microbial responses to nitrogen addition in three contrasting grassland ecosystems. Oecologia 154, 349-359.

Zhang XM, Wei HW, Chen QS, Han XG (2014) The counteractive effects of nitrogen addition and watering on soil bacterial communities in a steppe ecosystem. Soil Biol Biochem 72, 26-34.

Zhao FZ, Ren CJ, Shelton S, Wang Z, Pang G, Chen J, Wang J (2017) Grazing intensity influence soil microbial communities and their implications for soil respiration. Agric Ecosyst Environ 249, 50-56.

Zhao FZ, Ren CJ, Han XH, Yang GH, Wang J, Doughty R (2018) Changes of soil microbial and enzyme activities are linked to soil C, N and P stoichiometry in afforested ecosystems. For Ecol Manage 427, 289-295.

Zheng L, Chen H, Wang Y, Mao Q, Zheng M, Su Y, Li DJ (2020) Responses of soil microbial resource limitation to multiple fertilization strategies. Soil Till Res 196, 104474.

Zhu XM, Liu M, Kou YP, Liu DY, Liu Q, Zhang ZL. Jiang Z, Yin HJ (2020) Differential effects of $\mathrm{N}$ addition on the stoichiometry of microbes and extracellular enzymes in the rhizosphere and bulk soils of an alpine shrubland. Plant Soil, 1-17. 
790 Table 1 Results of four treatments of control (C), nitrogen addition (N), water addition (W), and water plus nitrogen addition (NW) on soil and microbial properties. Values are means with SE $(n=6)$. Different lowercase letters in the same line indicate statistically significant differences $(P<0.05)$.

\begin{tabular}{|c|c|c|c|c|}
\hline Treatment & $\mathrm{CK}$ & $\mathrm{N}$ & $\mathrm{W}$ & NW \\
\hline $\mathrm{pH}$ & $9.60 \pm 0.09 b$ & $9.46 \pm 0.08 b$ & $9.88 \pm 0.11 \mathrm{a}$ & $9.51 \pm 0.1 \mathrm{~b}$ \\
\hline $\mathrm{BD}\left(\mathrm{g} \mathrm{cm}^{-3}\right)$ & $1.47 \pm 0.02 \mathrm{a}$ & $1.46 \pm 0.02 \mathrm{a}$ & $1.39 \pm 0.03 b$ & $1.34 \pm 0.02 b$ \\
\hline $\mathrm{SM}(\%)$ & $2.15 \pm 0.13 b$ & $2.06 \pm 0.15 b$ & $4.95 \pm 0.71 \mathrm{a}$ & $4.84 \pm 0.16 \mathrm{a}$ \\
\hline $\operatorname{SOC}\left(\mathrm{g} \mathrm{kg}^{-1}\right)$ & $3.12 \pm 3.19 \mathrm{c}$ & $3.19 \pm 0.17 \mathrm{c}$ & $5.67 \pm 0.10 b$ & $7.83 \pm 0.17 \mathrm{a}$ \\
\hline $\mathrm{TN}\left(\mathrm{g} \mathrm{kg}^{-1}\right)$ & $0.22 \pm 0.01 \mathrm{c}$ & $0.29 \pm 0.02 b$ & $0.33 \pm 0.01 b$ & $0.41 \pm 0.01 \mathrm{a}$ \\
\hline $\mathrm{TP}\left(\mathrm{g} \mathrm{kg}^{-1}\right)$ & $0.42 \pm 0.05 b$ & $0.43 \pm 0.01 \mathrm{a}$ & $0.45 \pm 0.01 \mathrm{a}$ & $0.48 \pm 0.01 \mathrm{a}$ \\
\hline $\mathrm{C} / \mathrm{N}$ & $13.93 \pm 0.78 b$ & $10.95 \pm 0.55 \mathrm{c}$ & $16.98 \pm 0.79 \mathrm{a}$ & $18.58 \pm 0.99 a$ \\
\hline $\mathrm{C} / \mathrm{P}$ & $7.44 \pm 0.56 \mathrm{c}$ & $7.33 \pm 0.38 \mathrm{c}$ & $12.39 \pm 0.25 \mathrm{~b}$ & $16.21 \pm 0.42 \mathrm{a}$ \\
\hline $\mathrm{N} / \mathrm{P}$ & $0.53 \pm 0.02 \mathrm{~d}$ & $0.67 \pm 0.02 c$ & $0.73 \pm 0.02 b$ & $0.87 \pm 0.02 \mathrm{a}$ \\
\hline $\operatorname{DOC}\left(\mathrm{g} \mathrm{kg}^{-1}\right)$ & $132.86 \pm 5.21 \mathrm{c}$ & $159.74 \pm 4.66 b$ & $258.56 \pm 6.5 \mathrm{a}$ & $266.2 \pm 6.94 \mathrm{a}$ \\
\hline $\mathrm{NH}^{+}-\mathrm{N}\left(\mathrm{mg} \mathrm{kg}^{-1}\right)$ & $4.88 \pm 1.16 \mathrm{c}$ & $10.30 \pm 2.03 b$ & $8.88 \pm 1.91 b$ & $12.24 \pm 2.31 \mathrm{a}$ \\
\hline $\mathrm{NO}_{3}^{-}-\mathrm{N}\left(\mathrm{mg} \mathrm{kg}^{-1}\right)$ & $4.72 \pm 0.38 b$ & $8.37 \pm 0.36 \mathrm{a}$ & $3.05 \pm 0.12 \mathrm{c}$ & $8.30 \pm 0.34 \mathrm{a}$ \\
\hline $\mathrm{SAP}\left(\mathrm{mg} \mathrm{kg}^{-1}\right)$ & $7.42 \pm 0.60 \mathrm{c}$ & $6.84 \pm 0.58 \mathrm{c}$ & $10.39 \pm 0.61 \mathrm{~b}$ & $13.29 \pm 0.59 \mathrm{a}$ \\
\hline DOC/AN & $19.28 \pm 4.45 \mathrm{a}$ & $8.64 \pm 4.47 \mathrm{c}$ & $18.60 \pm 0.61 \mathrm{a}$ & $12.79 \pm 3.76 \mathrm{~b}$ \\
\hline DOC/SAP & $18.77 \pm 1.92 \mathrm{~b}$ & $24.30 \pm 2.52 \mathrm{a}$ & $26.61 \pm 2.52 \mathrm{a}$ & $21.68 \pm 2.32 \mathrm{a}$ \\
\hline AN/SAP & $1.27 \pm 0.29 \mathrm{c}$ & $2.84 \pm 0.52 \mathrm{a}$ & $1.46 \pm 0.47 \mathrm{c}$ & $1.72 \pm 0.48 \mathrm{~b}$ \\
\hline $\mathrm{MBC}\left(\mathrm{mg} \mathrm{kg}^{-1}\right)$ & $265.54 \pm 10.05 \mathrm{c}$ & $283.34 \pm 7.01 \mathrm{c}$ & $337.05 \pm 9.09 \mathrm{~b}$ & $384.37 \pm 8.9 \mathrm{a}$ \\
\hline MBN (mg kg $\left.{ }^{-1}\right)$ & $48.25 \pm 2.59 \mathrm{c}$ & $66.34 \pm 3.52 b$ & $57.25 \pm 3.91 \mathrm{c}$ & $74.30 \pm 3.95 \mathrm{a}$ \\
\hline $\operatorname{MBP}\left(\mathrm{mg} \mathrm{kg}^{-1}\right)$ & $7.29 \pm 0.0 .31 \mathrm{c}$ & $7.85 \pm 0.71 \mathrm{c}$ & $8.26 \pm 1.01 \mathrm{~b}$ & $10.76 \pm 1.03 \mathrm{a}$ \\
\hline CUE & $0.22 \pm 0.02 b$ & $0.17 \pm 0.0 .11 \mathrm{c}$ & $0.26 \pm 0.12 \mathrm{a}$ & $0.25 \pm 0.08 \mathrm{a}$ \\
\hline
\end{tabular}


Table 2 Summary of Results ( $F$ - and $P$-values) of linear mixed models on the main effects of nitrogen $(\mathrm{N})$ addition, water $(\mathrm{W})$ addition, and water plus nitrogen addition $(\mathrm{NW})$ on the on soil and microbial properties.

\begin{tabular}{|c|c|c|c|c|c|c|}
\hline \multirow[t]{2}{*}{ Treatment } & \multicolumn{2}{|c|}{$\mathrm{N}$} & \multicolumn{2}{|c|}{ W } & \multicolumn{2}{|c|}{ NW } \\
\hline & $F$ & $P$ & $F$ & $P$ & $F$ & $P$ \\
\hline $\mathrm{pH}$ & 4.226 & 0.053 & 44.687 & $<0.001$ & 1.635 & 0.216 \\
\hline BD & 1.12 & 0.302 & 16.039 & 0.001 & 0.324 & 0.575 \\
\hline SM & 0.063 & 0.804 & 45.968 & $<0.001$ & 0.002 & 0.969 \\
\hline SOC & 5.643 & 0.028 & 58.883 & $<0.001$ & 4.935 & 0.038 \\
\hline $\mathrm{TN}$ & 40.111 & $<0.001$ & 97.946 & $<0.001$ & 0.319 & 0.579 \\
\hline $\mathrm{TP}$ & 37.221 & $<0.001$ & 156.475 & $<0.001$ & 0.907 & 0.352 \\
\hline $\mathrm{C}: \mathrm{N}$ & 0.401 & 0.534 & 238.74 & $<0.001$ & 4.393 & 0.049 \\
\hline C:P & 3.626 & 0.071 & 50.548 & $<0.001$ & 4.058 & 0.058 \\
\hline $\mathrm{N}: \mathrm{P}$ & 39.921 & $<0.001$ & 84.413 & $<0.001$ & 0.007 & 0.933 \\
\hline DOC & 6.682 & 0.018 & 302.2 & $<0.001$ & 2.075 & 0.165 \\
\hline $\mathrm{NH}_{4}{ }^{+}-\mathrm{N}$ & 32.04 & $<0.001$ & 0.886 & 0.358 & 0.683 & 0.418 \\
\hline $\mathrm{NO}_{3}-\mathrm{N}$ & 34.781 & $<0.001$ & 8.853 & 0.007 & 1.718 & 0.205 \\
\hline SAP & 1.098 & 0.307 & 18.007 & $<0.001$ & 2.457 & 0.133 \\
\hline DOC/AN & 10.534 & 0.004 & 0.469 & 0.502 & 0.906 & 0.352 \\
\hline DOC/SAP & 0.014 & 0.907 & 1.028 & 0.323 & 4.122 & 0.056 \\
\hline AN/SAP & 11.725 & 0.003 & 3.106 & 0.093 & 6.055 & 0.023 \\
\hline $\mathrm{MBC}$ & 4.708 & 0.042 & 32.991 & $<0.001$ & 0.969 & 0.337 \\
\hline MBN & 85.988 & $<0.001$ & 20.029 & $<0.001$ & 0.077 & 0.785 \\
\hline MBP & 3.049 & 0.096 & 4.949 & 0.038 & 1.241 & 0.278 \\
\hline CUE & 11.825 & 0.003 & 2.056 & 0.167 & 1.611 & 0.219 \\
\hline
\end{tabular}


Table 3 Summary of stepwise regression models to reveal soil microbial C limitation and N/P limitation determining by soil and microbial properties. Note: Soil microbial $\mathrm{C}$ limitation is represented by vector lengths; Soil microbial N/P limitation is represented by vector angles, angles $<45^{\circ}$ represent $\mathrm{N}$ limitation, angles $>45^{\circ}$ represent $\mathrm{P}$ limitation.

804

\begin{tabular}{llll}
\hline & Equation & $r^{2}$ & $p$ \\
\hline Vector length & $y=-0.12 \mathrm{SM}+0.013 \mathrm{SOC}-1.29 \mathrm{~N} / \mathrm{P}+0.865$ & 0.61 & $* * *$ \\
Vector angle & $\mathrm{y}=2.43 \mathrm{SM}-1.95 \mathrm{SAP}+2.38 \mathrm{AN} / \mathrm{SAP}-0.08 \mathrm{MBC}+60.23$ & 0.52 & $* * *$
\end{tabular}




\section{Figure captions:}

Figure 1 Effects of $\mathrm{N}$ addition and increased precipitation on soil microbial C-, N- and Pacquiring enzyme activities (A-C, per g soil) and specific enzyme activities (D-F, per mg $\mathrm{MBC})$. CK, N, W, and NW represent the control, nitrogen addition, water addition, combination treatment with water plus nitrogen addition, respectively. The results of the linear mixed effects models for the main factors ( $\mathrm{N}$ and $\mathrm{W}$ ) and their interaction on soil microbial nutrient acquiring enzyme activities are shown in the top-figures. Different lowercase letters below the data indicate statistically significant differences among the different treatments $(P<0.05)$. Values are means with SE $(\mathrm{n}=6)$. C-acquiring enzyme $(\mathrm{BG}$, $\beta$-1,4-glucosidase; $\mathrm{CBH}, \beta$-D-cellobiosidase), C-acquiring enzyme (NAG, N-acetyl- $\beta$-Dglucosaminidase; LAP, leucine aminopeptidase), P-acquiring enzyme (AP, acid phosphatase). MBC, microbial biomass C.

Figure 2 Stoichiometry of C-, N- and P-acquiring enzyme activities (A-C) by N and water additions and their relationships (D-F). Values are means with SE $(n=6)$. The results of the linear mixed effects models for the main factors $(\mathrm{N}$ and $\mathrm{W})$ and their interaction on the stoichiometry of C-, N- and P-acquiring enzyme activities (A-C) are shown in the topfigures. CK, N, W, and NW represent the control, nitrogen addition, water addition, water plus nitrogen addition, respectively. Different lowercase letters indicate significant differences at $P<0.05$ using Duncan tests.

Figure 3 Extracellular enzyme stoichiometry of the relative proportions of $\mathrm{C}$ to $\mathrm{N}$ acquisition versus $\mathrm{C}$ to $\mathrm{P}$ acquisition $(\mathrm{A})$, the variation of vector length and angle (B and $\mathrm{C}$ ) and their relationships (D). Values are means with SE $(n=6)$. The results of the linear mixed effects models for the main factors ( $\mathrm{N}$ and $\mathrm{W}$ ) and their interaction on the stoichiometry of C-, Nand P-acquiring enzyme activities (A-C) are shown in the top-figures. The results of the linear mixed effects models for the main factors $(\mathrm{N}$ and $\mathrm{W})$ and their interaction on the stoichiometry of C-, N- and P-acquiring enzyme activities (A-C) are shown in the topfigures. Note: black lines indicate linear model fits. The significance level is $P<0.05$.

Figure $4 \mathrm{~N}$-induced changes in the $\mathrm{C}$ and $\mathrm{P}$ limitation in the unwatered and watered plots (A), and water-induced changes in the $\mathrm{C}$ and $\mathrm{P}$ limitation (B) in the unfertilized and fertilized plots. Microbial C limitation, represented by vector length; microbial P limitation, represented by vector angle. $P$-values represent the significant difference between the two bars.

Figure 5 Variation partitioning analysis (VPA) was applied to determine the contributions of 
soil physical properties, soil nutrients, nutrient ratios and microbial properties to (A) vector length and (B) vector angle. Vector length, microbial $\mathrm{C}$ limitation; vector angle, microbial N/P limitation. Soil physical properties include $\mathrm{pH}$; BD, bulk density; SM, soil moisture content. Soil nutrients include: SOC, soil organic C; TN, soil total N; TP, soil total P; DOC, soil dissolved organic $\mathrm{C} ; \mathrm{NO}_{3}{ }^{-}-\mathrm{N}^{+}, \mathrm{NH}_{4}{ }^{+}-\mathrm{N}$; SAP, soil available P. Nutrient ratios include: $\mathrm{C}: \mathrm{N}$, the ratio of SOC to $\mathrm{TN} ; \mathrm{N}: \mathrm{P}$, the ratio of TN to TP; DOC:AN, the ratio of DOC to AN; DOC:SAP, the ratio of DOC to SAP; AN:SAP, the ratio of AN to SAP. Microbial properties include: $\mathrm{MBC}, \mathrm{MBN}, \mathrm{MBP}$ and CUE. $\mathrm{AN}, \mathrm{NO}_{3}{ }^{-}-\mathrm{N}$ and $\mathrm{NH}_{4}{ }^{+}-\mathrm{N}$.

Figure 6 The structural equation model (SEM) evaluating the impacts of controlling factors on vector length (A) and angle (B). The dashed and solid lines indicate negative and positive coefficients, respectively; the thickness of the arrows indicates the magnitude of the standardized path coefficient. RMSEA, root mean square error of approximation; GFI, goodness-of-fit index. Vector length, microbial C limitation; vector angle, microbial N/P 

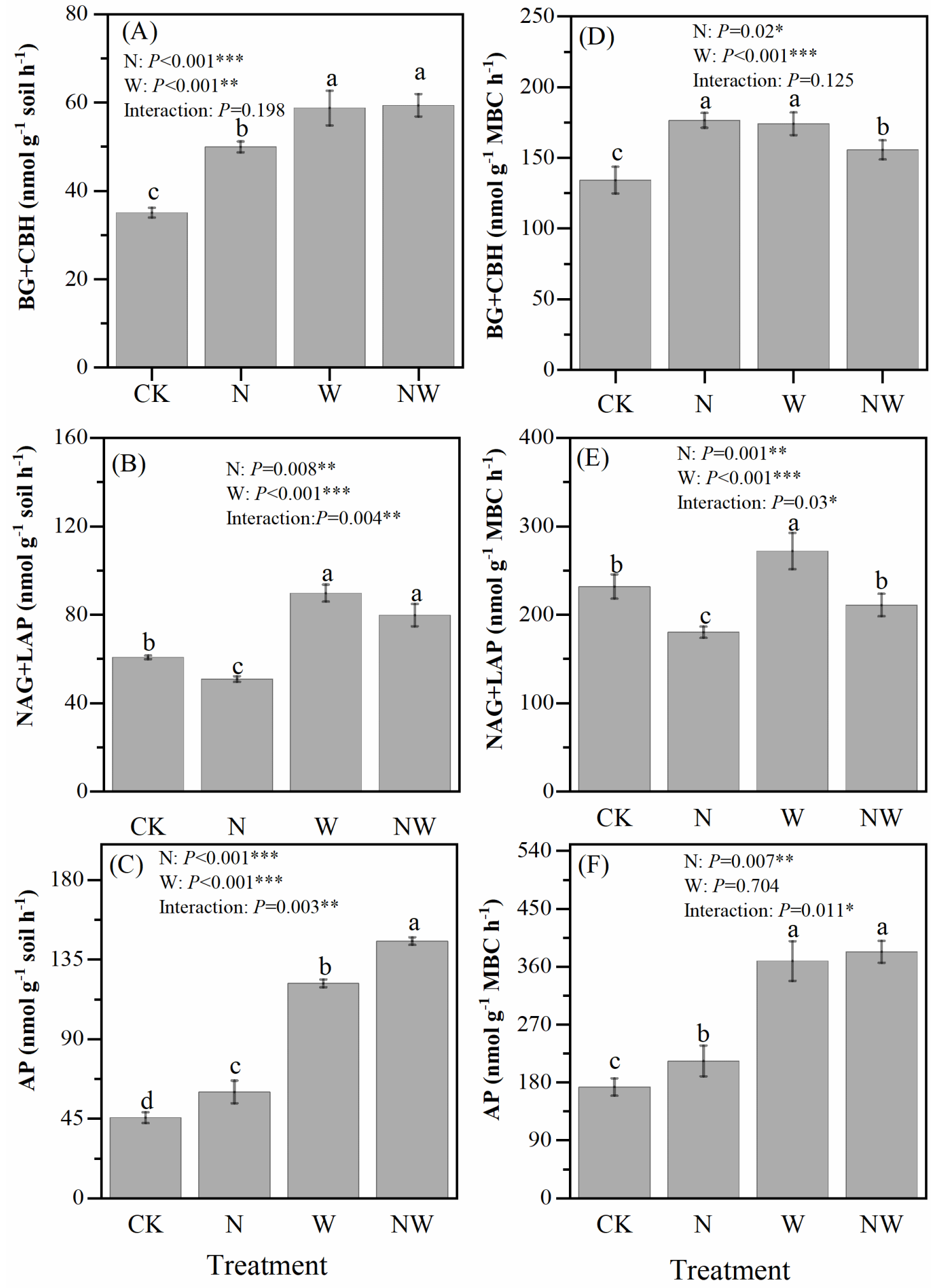

Fig. 1 

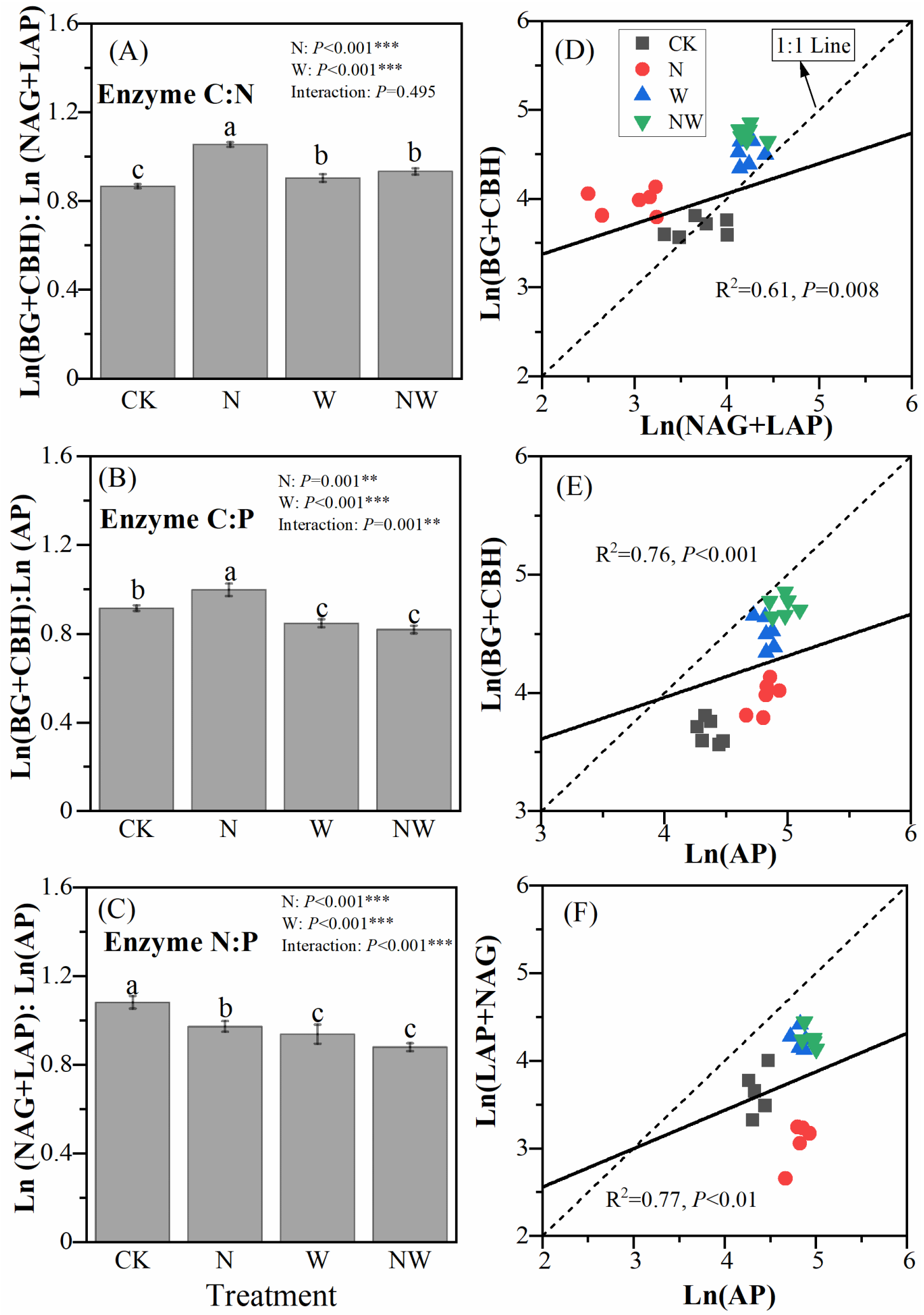

Fig. 2 


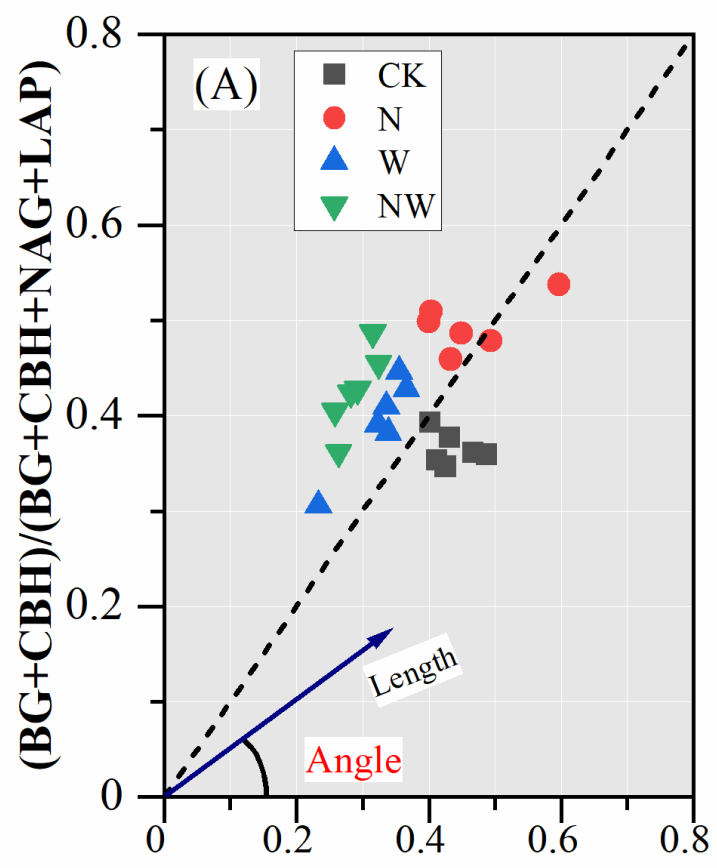

$(\mathrm{BG}+\mathrm{CBH}) /(\mathbf{B G}+\mathbf{C B H}+\mathbf{A P})$
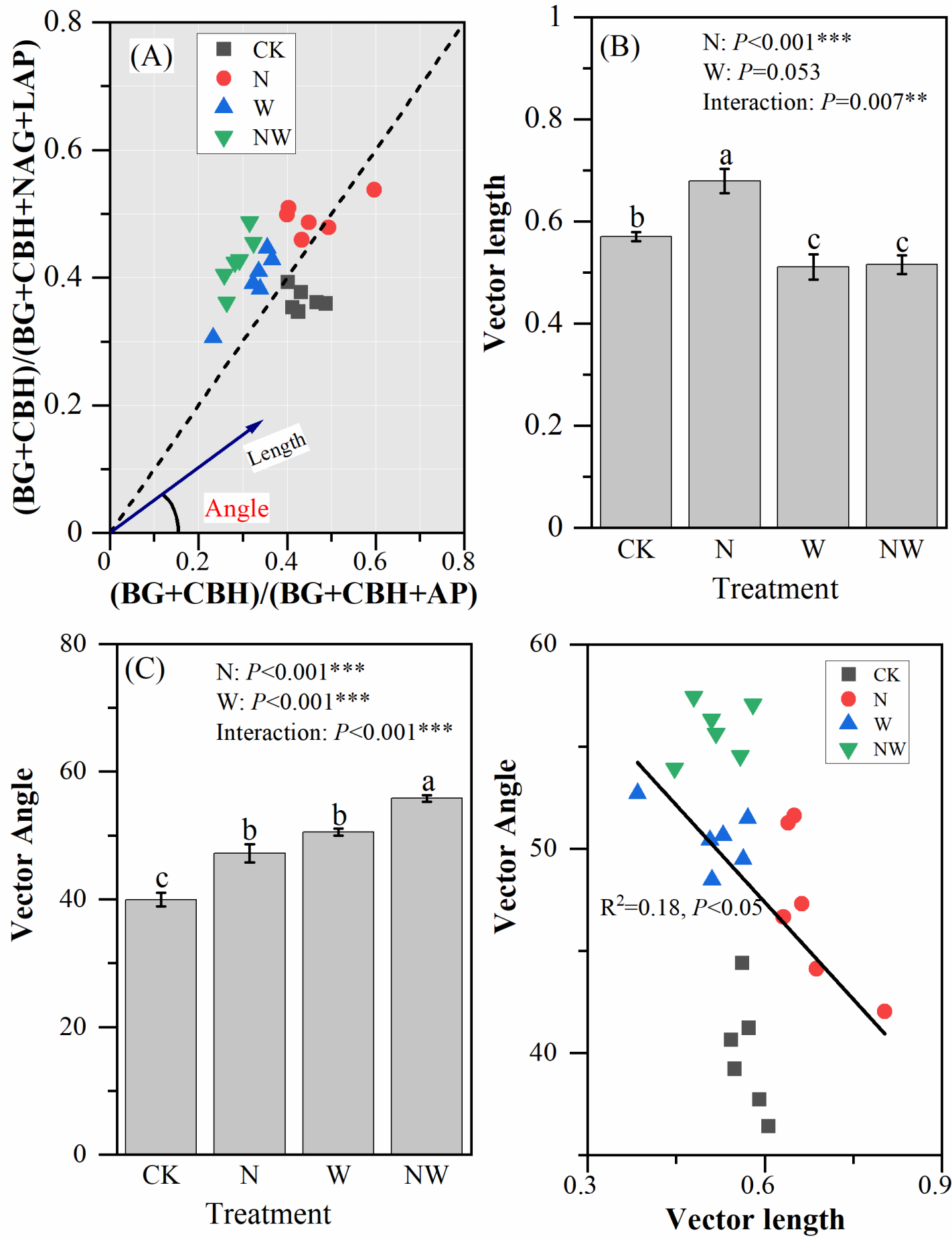

864

Fig. 3 

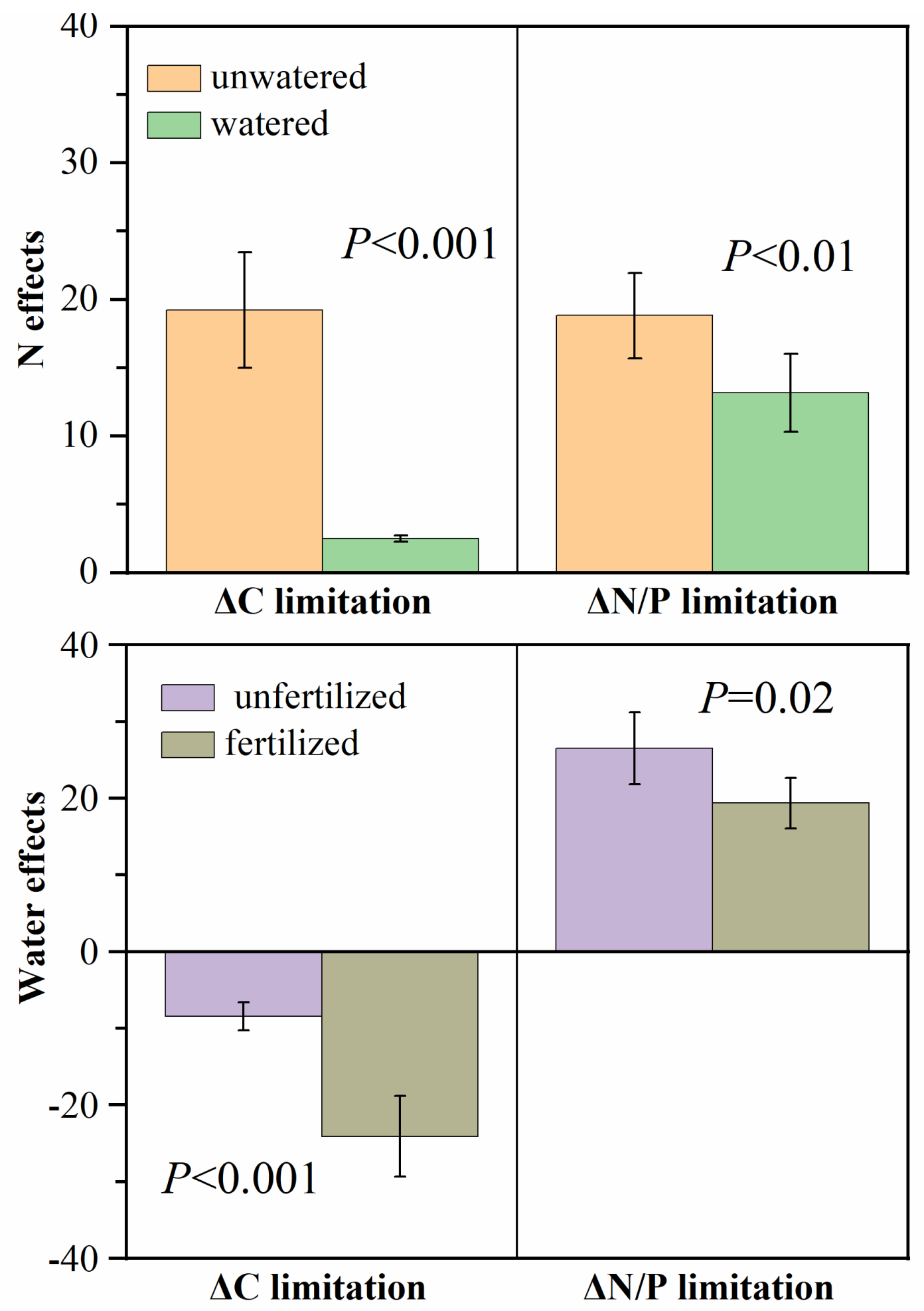

Fig.4 

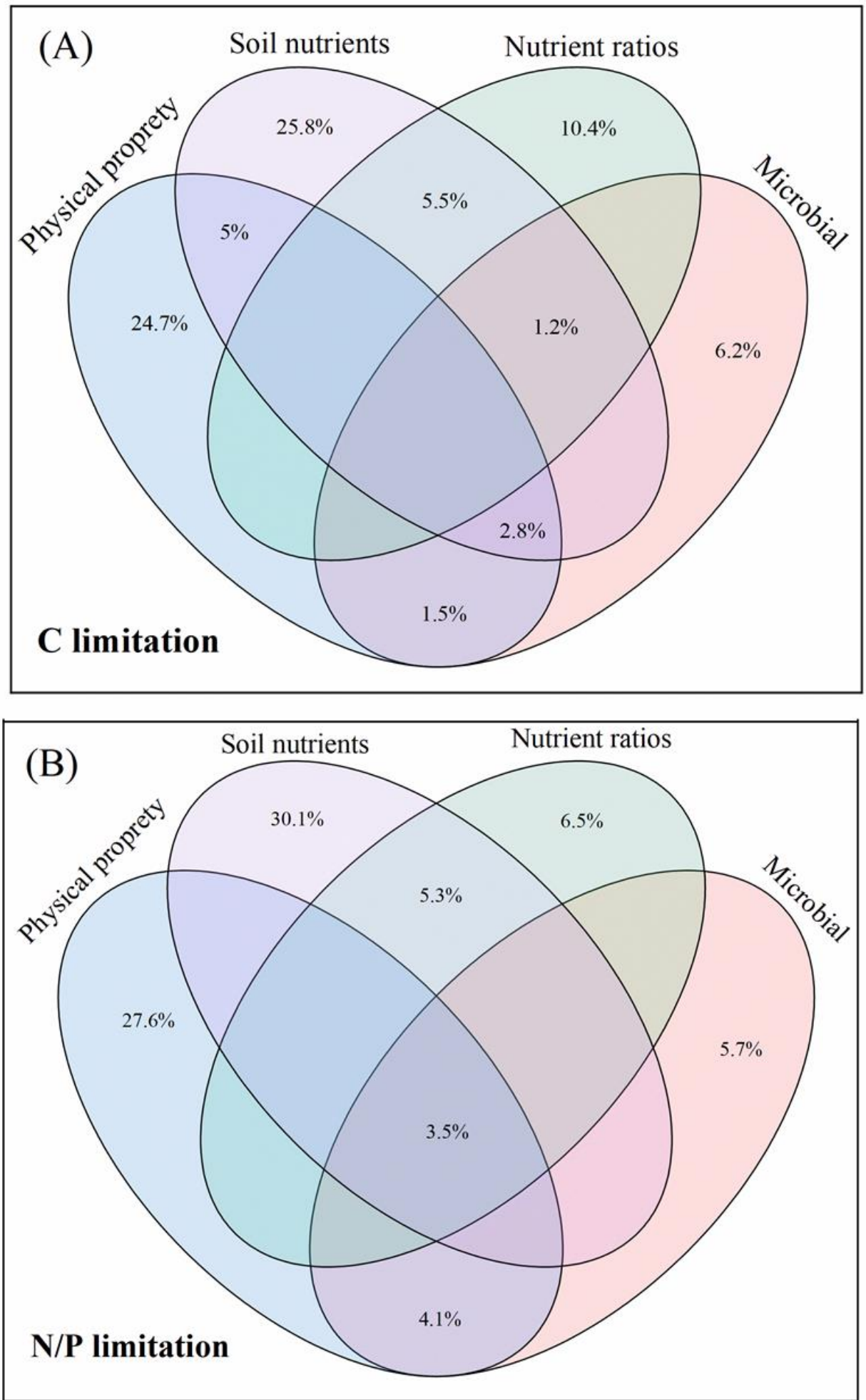
(A)

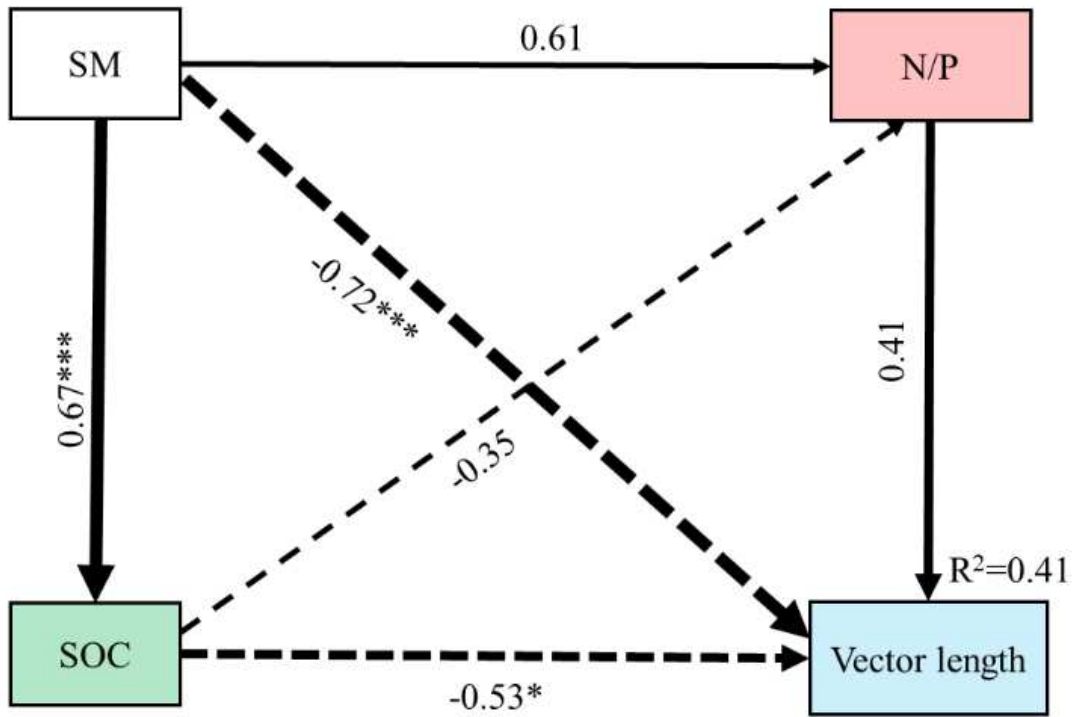

$\chi^{2}=3.3, \mathrm{df}=2, P=0.71, \mathrm{RMSEA}=0.034, \mathrm{AIC}=41.25, \mathrm{GFI}=0.95$

(B)

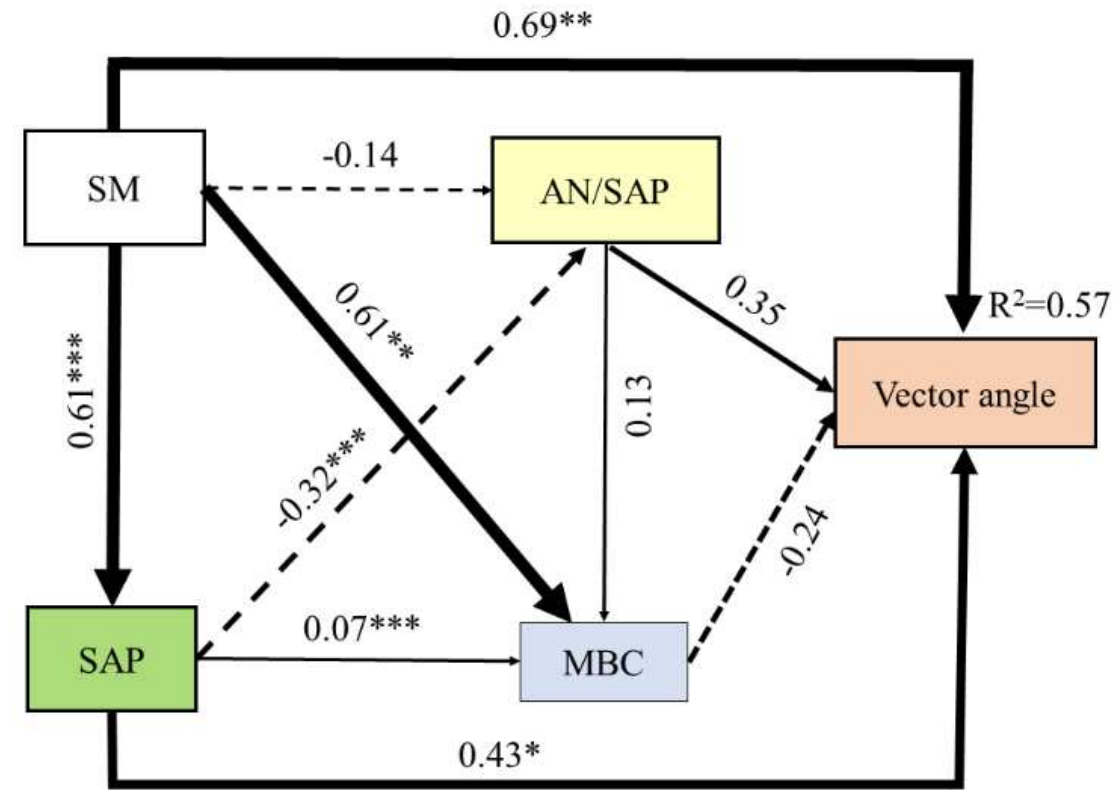

$\chi^{2}=1.616, \mathrm{df}=2, P=0.18, \mathrm{RMSEA}=0.015, \mathrm{AIC}=28.3, \mathrm{GFI}=0.94$

Fig.6 
Figures
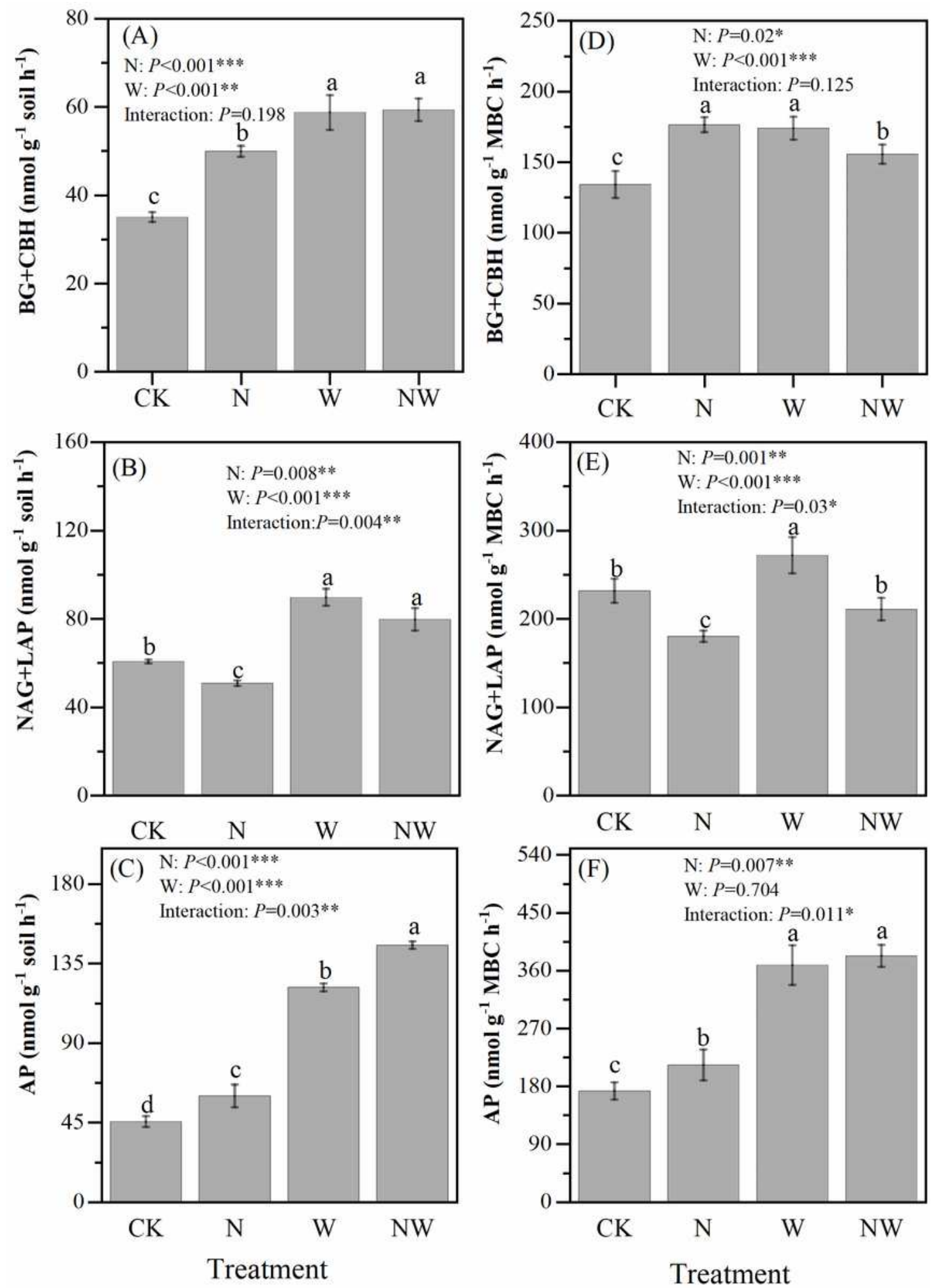

Figure 1

Effects of $\mathrm{N}$ addition and increased precipitation on soil microbial $\mathrm{C}-, \mathrm{N}$ - and $\mathrm{P}$-acquiring enzyme activities (A-C, per g soil) and specific enzyme activities (D-F, per mg MBC). CK, N, W, and NW represent the control, nitrogen addition, water addition, combination treatment with water plus nitrogen addition, 
respectively. The results of the linear mixed effects models for the main factors ( $N$ and $W$ ) and their interaction on soil microbial nutrient acquiring enzyme activities are shown in the top-figures. Different lowercase letters below the data indicate statistically significant differences among the different treatments $(P<0.05)$. Values are means with $S E(n=6)$. C-acquiring enzyme $(B G, \beta-1,4$-glucosidase; $C B H, \beta-$ D-cellobiosidase), C-acquiring enzyme (NAG, N-acetyl-- $\beta$-D-glucosaminidase; LAP, leucine aminopeptidase), P-acquiring enzyme (AP, acid phosphatase). MBC, microbial biomass $\mathrm{C}$.
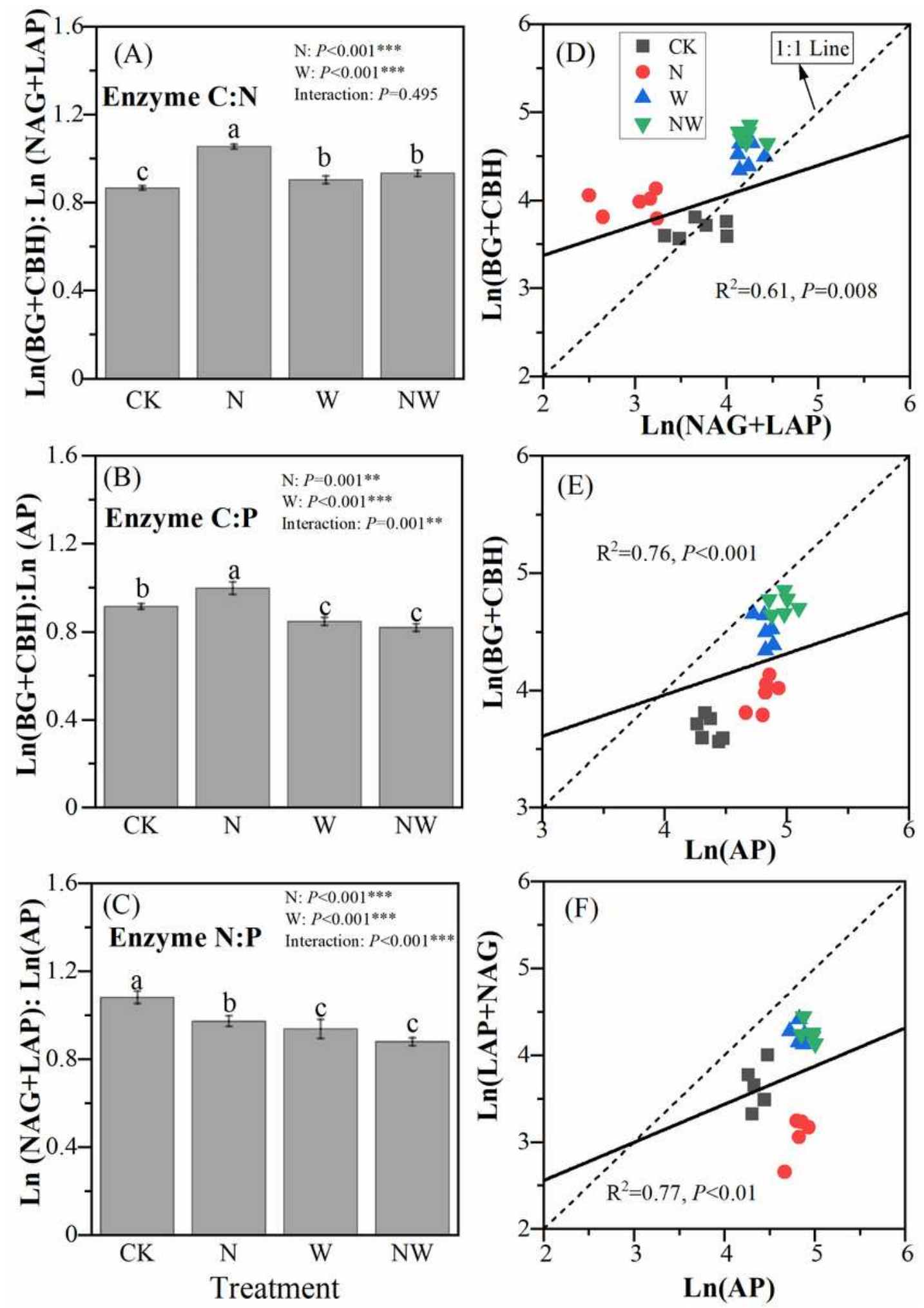

Figure 2 
Stoichiometry of $\mathrm{C}-, \mathrm{N}$ - and P-acquiring enzyme activities (A-C) by $\mathrm{N}$ and water additions and their relationships $(D-F)$. Values are means with $S E(n=6)$. The results of the linear mixed effects models for the main factors ( $\mathrm{N}$ and $\mathrm{W}$ ) and their interaction on the stoichiometry of $\mathrm{C}-, \mathrm{N}$ - and P-acquiring enzyme activities (A-C) are shown in the top-figures. $\mathrm{CK}, \mathrm{N}, \mathrm{W}$, and NW represent the control, nitrogen addition, water addition, water plus nitrogen addition, respectively. Different lowercase letters indicate significant differences at $\mathrm{P}<0.05$ using Duncan tests.
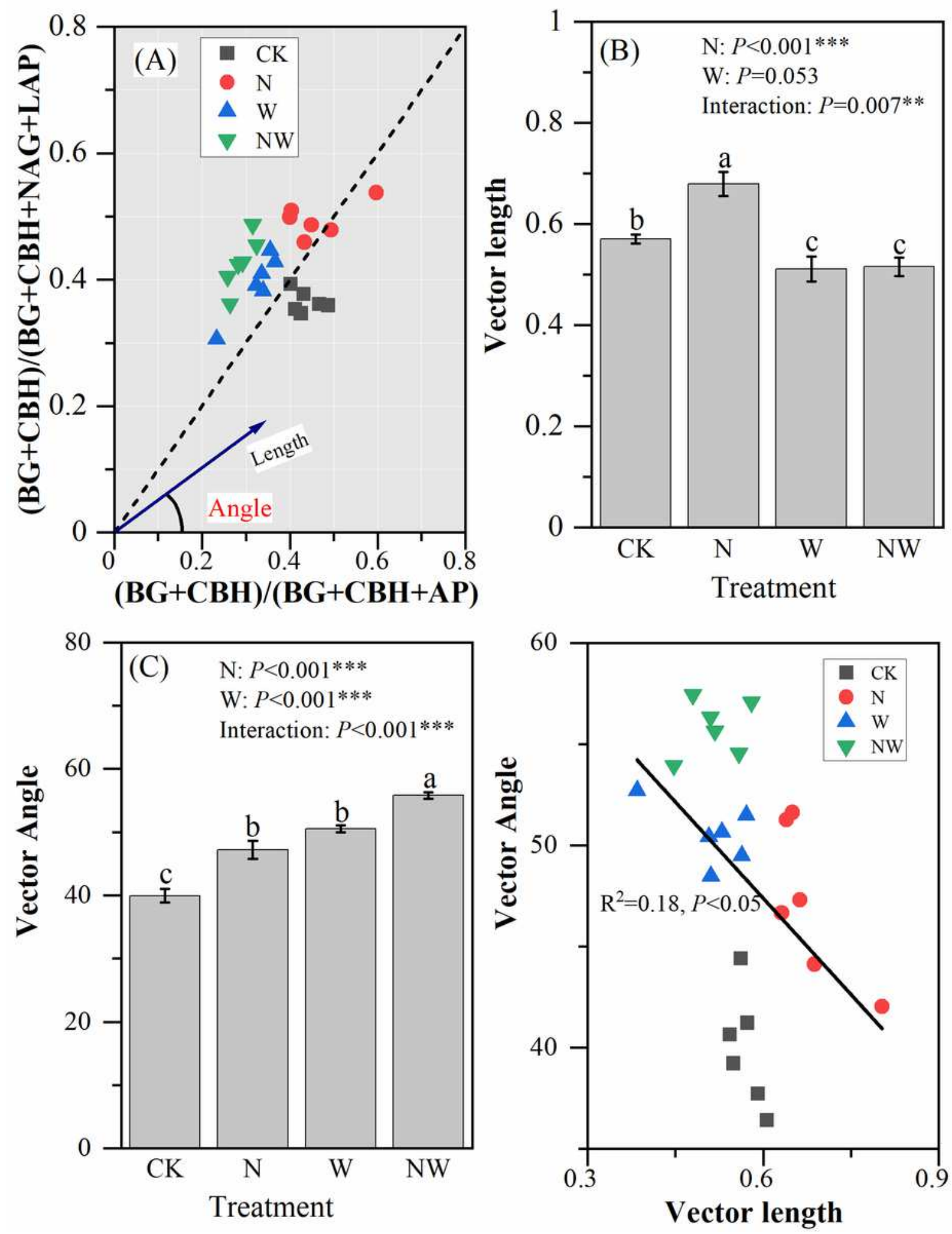

Figure 3 
Extracellular enzyme stoichiometry of the relative proportions of $\mathrm{C}$ to $\mathrm{N}$ acquisition versus $\mathrm{C}$ to $\mathrm{P}$ acquisition (A), the variation of vector length and angle (B and $C$ ) and their relationships (D). Values are means with $S E(n=6)$. The results of the linear mixed effects models for the main factors $(N$ and $W)$ and their interaction on the stoichiometry of $\mathrm{C}$-, $\mathrm{N}$ - and P-acquiring enzyme activities $(\mathrm{A}-\mathrm{C})$ are shown in the top-figures. The results of the linear mixed effects models for the main factors ( $N$ and $W$ ) and their interaction on the stoichiometry of $\mathrm{C}$-, $\mathrm{N}$ - and $\mathrm{P}$-acquiring enzyme activities $(\mathrm{A}-\mathrm{C})$ are shown in the topfigures. Note: black lines indicate linear model fits. The significance level is $P<0.05$.
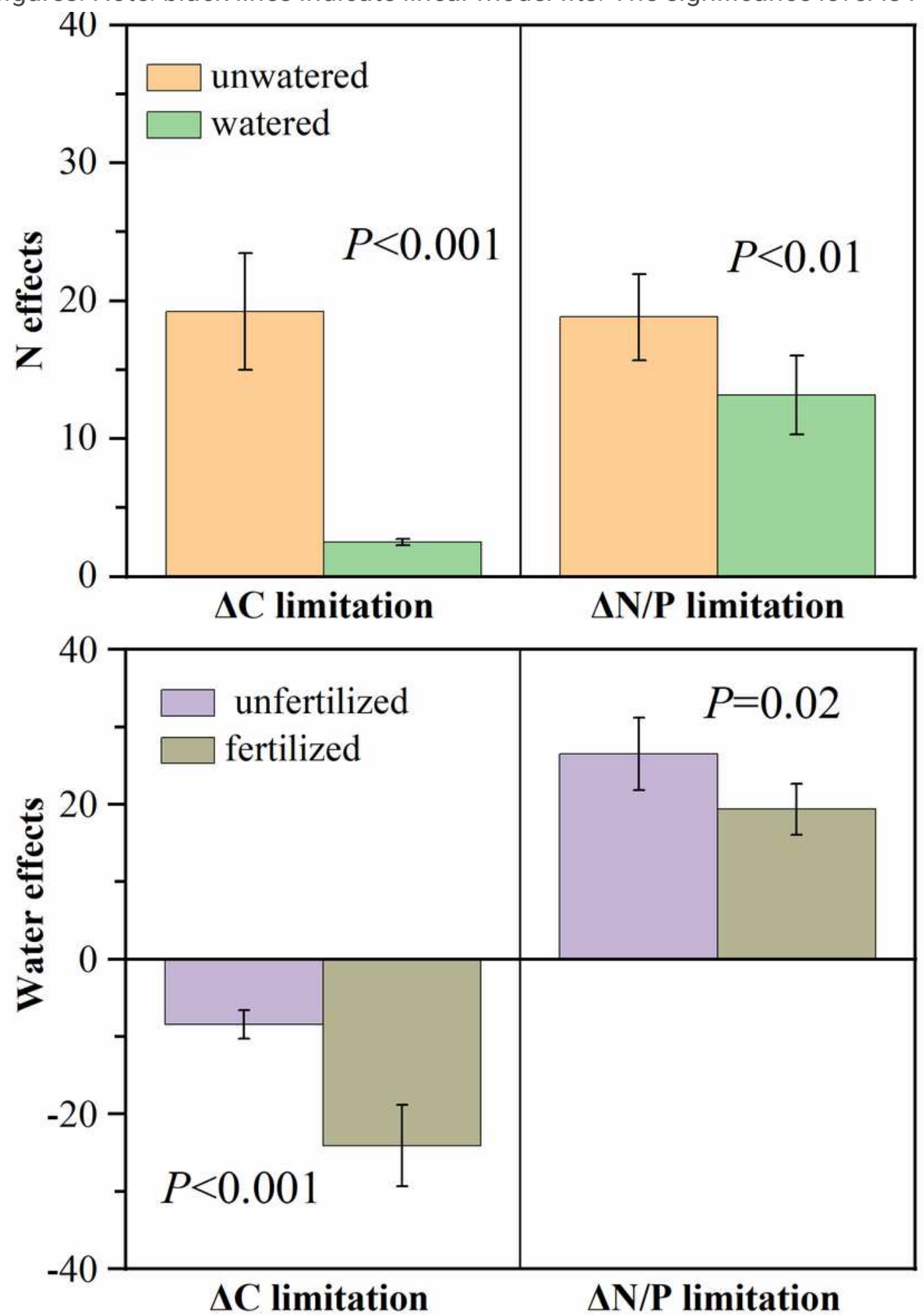
Figure 4

$\mathrm{N}$-induced changes in the $\mathrm{C}$ and $\mathrm{P}$ limitation in the unwatered and watered plots $(\mathrm{A})$, and water-induced changes in the $\mathrm{C}$ and $\mathrm{P}$ limitation (B) in the unfertilized and fertilized plots. Microbial $C$ limitation, represented by vector length; microbial P limitation, represented by vector angle. P-values represent the significant difference between the two bars.
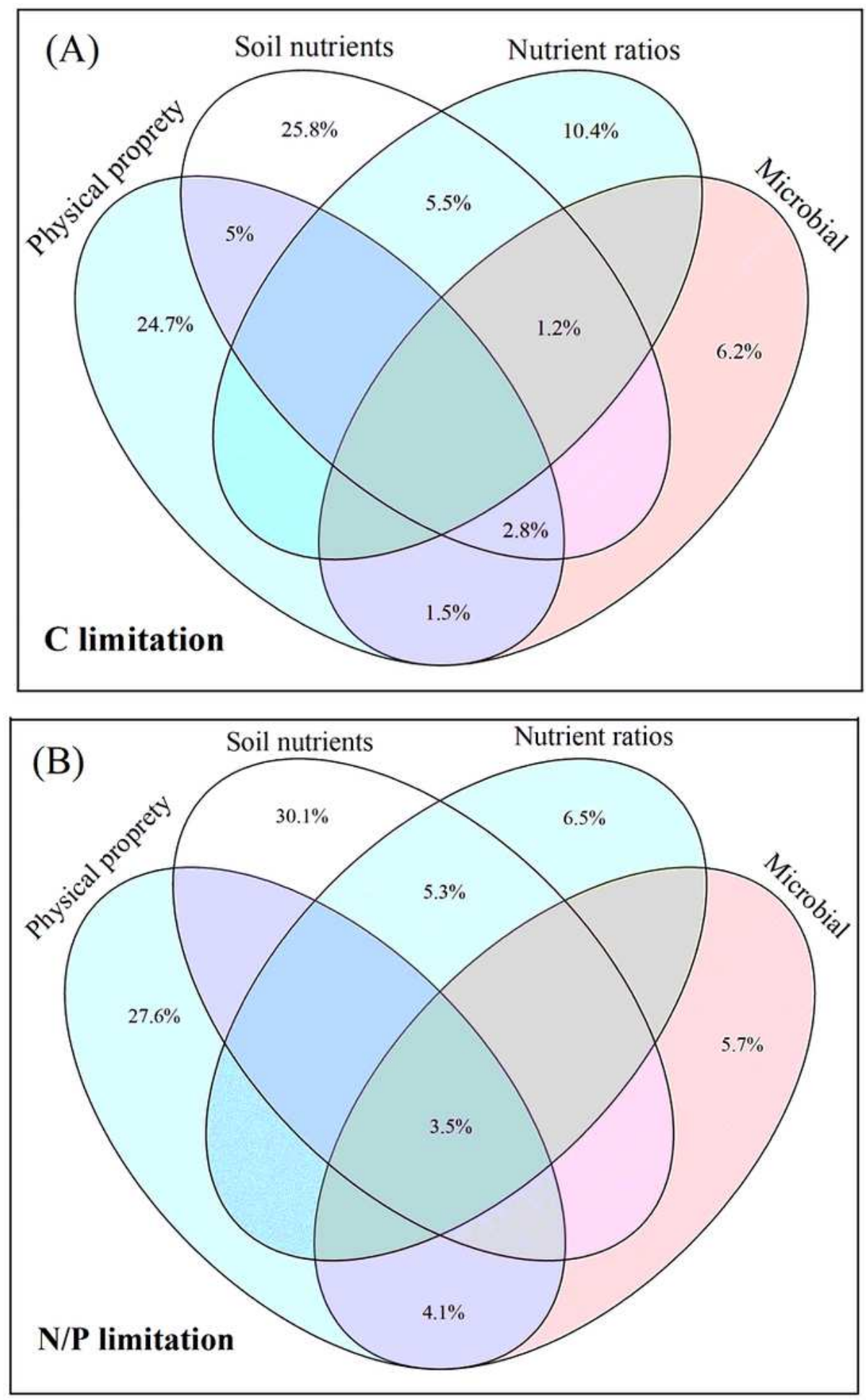

Figure 5 
Variation partitioning analysis (VPA) was applied to determine the contributions of soil physical properties, soil nutrients, nutrient ratios and microbial properties to $(A)$ vector length and $(B)$ vector angle. Vector length, microbial C limitation; vector angle, microbial N/P limitation. Soil physical properties include $\mathrm{pH}$; BD, bulk density; SM, soil moisture content. Soil nutrients include: SOC, soil organic C; TN, soil total N; TP, soil total P; DOC, soil dissolved organic C; NO3--N+, NH4+-N; SAP, soil available P. Nutrient ratios include: $\mathrm{C}: \mathrm{N}$, the ratio of $S O C$ to $T N$; $N: P$, the ratio of TN to TP; DOC:AN, the ratio of DOC to AN; DOC:SAP, the ratio of DOC to SAP; AN:SAP, the ratio of AN to SAP. Microbial properties include: MBC, MBN, MBP and CUE. AN, NO3--N and NH4+-N. 
(A)

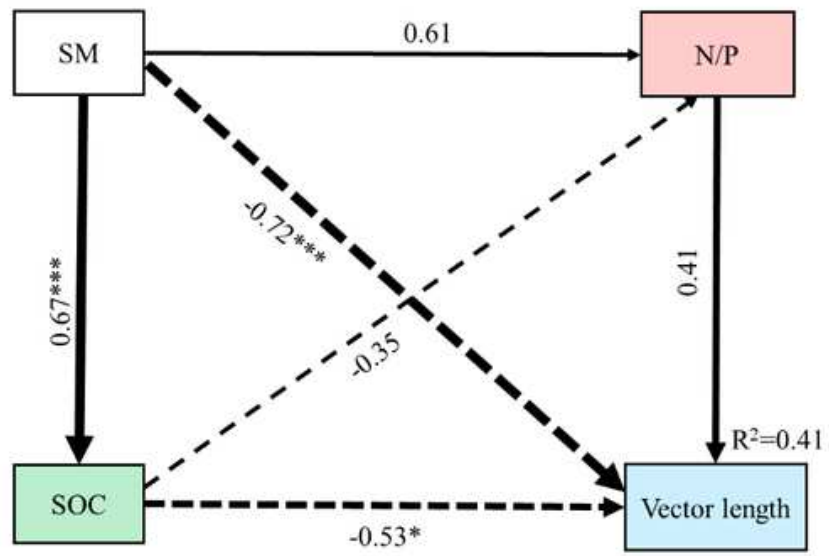

$\chi^{2}=3.3, \mathrm{df}=2, P=0.71, \mathrm{RMSEA}=0.034, \mathrm{AIC}=41.25, \mathrm{GFI}=0.95$

(B)

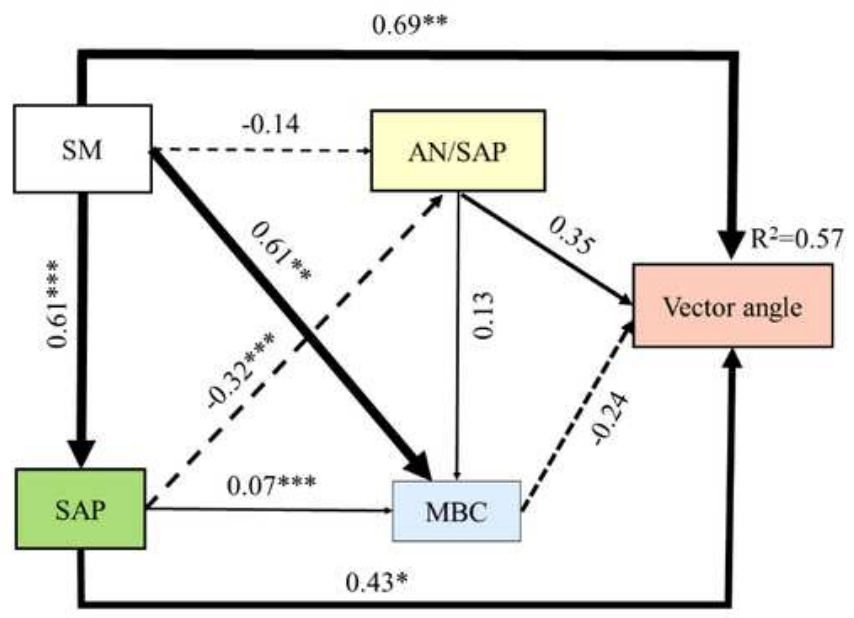

$\chi^{2}=1.616, \mathrm{df}=2, P=0.18, \mathrm{RMSEA}=0.015, \mathrm{AIC}=28.3, \mathrm{GFI}=0.94$

\section{Figure 6}

The structural equation model (SEM) evaluating the impacts of controlling factors on vector length (A) and angle (B). The dashed and solid lines indicate negative and positive coefficients, respectively; the thickness of the arrows indicates the magnitude of the standardized path coefficient. RMSEA, root mean square error of approximation; GFI, goodness-of-fit index. Vector length, microbial C limitation; vector angle, microbial N/P limitation. 


\section{Supplementary Files}

This is a list of supplementary files associated with this preprint. Click to download.

- Supplementaryinformation.docx 